\title{
KEJAHATAN LINGKUNGAN OLEH KORPORASI: MENCARI BENTUK PERTANGGUNGJAWABAN KORPORASI DAN PEMIMPIN/PENGURUS KORPORASI UNTUK KEJAHATAN LINGKUNGAN DI INDONESIA ${ }^{1}$
}

\author{
Andri G. Wibisana \\ * Dosen Hukum Lingkungan Fakultas Hukum Universitas Universitas Indonesia \\ Korespondensi: mragw@yahoo.com. \\ Naskah dikirim: 31 Mei 2016 \\ Naskah diterima untuk diterbitkan: 14 Juni 2016
}

\begin{abstract}
It is very likely that most environmental crimes involve corporation, in the sense that the crimes were conducted within the scope of corporation and on behalf of the corporation. This contribution attempts to answer the questions of how corporate criminal liability has evolved in several jurisdictions, and how this concept has been interpreted and implemented in Indonesia. The contribution explains the development of corporate criminal liability, and classifies it into liability for corporation and liability for corporate officers. Based on such theoretical foundations, the contribution critically analyses the formulation of corporate criminal liability and officers' liability in various legislations related to environmental protection and in various court decisions in Indonesia. It is observed that some laws and rulings failed to make a clear distinction between criminal liability for corporation and that for its high ranking officers. The failure result in some rulings where a corporation being held liable although it was not a defendant, or a director was likely to be put in jail although he was not a defendant. The contribution recommends some changes in corporate and officers' criminal liability in Indonesia. In particular, this contribution criticizies the use of individual criminal liability, and argues that to hold an officer liable the government needs to prove the contribution of the officer in the criminal conduct.
\end{abstract}

Keywords: corporate criminal liability, officers' liability, environmental crimes

1 Artikel ini merupakan perbaikan dan perluasan dari artikel dengan judul sama yang telah disampaikan pada Seminar Nasional Lingkungan Hidup 2016, Fakultas Hukum Universitas Andalas, Padang, 20 April 2016.

Penulis berterima kasih kepada Nathalina Naibaho dan Adhimas Putrastyo Hutomo atas komentarnya untuk draft awal dari tulisan ini. Terima kasih pula untuk ELSAM yang telah mengizinkan penulis berkontribusi dalam diskusi mengenai RKUHP. Tentu saja kekeliruan yang ada dalam tulisan ini tetaplah merupakan tanggung jawab penulis sepenuhnya. 


\begin{abstract}
Abstrak
Sangat mungkin bahwa sebagian besar kejahatan lingkungan melibatkan korporasi, dalam arti bahwa kejahatan dilakukan dalam lingkup korporasi dan atas nama korporasi. Kontribusi ini mencoba untuk menjawab pertanyaanpertanyaan tentang bagaimana tanggung jawab pidana korporasi telah berkembang dalam beberapa yurisdiksi, dan bagaimana konsep ini telah ditafsirkan dan diimplementasikan di Indonesia. kontribusi menjelaskan perkembangan pertanggungjawaban pidana korporasi, dan mengklasifikasikan menjadi kewajiban bagi perusahaan dan kewajiban untuk pejabat perusahaan. Berdasarkan teori dasar tersebut, tulisan ini kritis menganalisa perumusan pertanggungjawaban pidana korporasi dan kewajiban petugas 'dalam berbagai peraturan perundang-undangan yang terkait dengan perlindungan lingkungan dan dalam berbagai keputusan pengadilan di Indonesia. Diamati bahwa beberapa hukum dan putusan, gagal membuat perbedaan yang jelas antara tanggung jawab pidana untuk korporasi dan untuk pejabat yang tinggi. Hasil kegagalan dalam beberapa putusan terhadap sebuah perusahaan yang dimintai tanggung jawab meskipun itu bukan terdakwa, atau direktur kemungkinan besar akan dimasukkan ke dalam penjara meskipun ia bukan terdakwa. Tulisan ini merekomendasikan beberapa perubahan dalam perusahaan dan tanggung jawab pidana pejabat di Indonesia. Secara khusus, tulisan ini mengkritisi penggunaan pertanggungjawaban pidana individu, dan berpendapat bahwa untuk mengadakan petugas tanggung jawab pemerintah perlu membuktikan kontribusi dari petugas dalam melakukan kejahatan.
\end{abstract}

Kata kunci: tanggung jawab pidana korporasi, kewajiban petugas, kejahatan lingkungan

\title{
I. Pendahuluan
}

Sebagian besar tindak pidana lingkungan hidup seringkali melibatkan korporasi, dalam arti bahwa tindak pidana tersebut dilakukan dalam lingkup kerja korporasi dan untuk menguntungkan korporasi. Setidaknya sejak tahun 1997, melalui UU No. 23 Tahun 1997 tentang Pengelolaan Lingkungan Hidup (UUPLH) ${ }^{2}$ Indonesia telah mencoba untuk merumuskan ketentuan mengenai pertanggungjawaban korporasi. Beberapa putusan pengadilan juga memperlihatkan bagaimana pertanggungjawaban korporasi diterapkan di Indonesia.

Menurut Fisse dan Braithwaite, terdapat dua puluh hal penting (desiderata) yang perlu dipertimbangkan dalam mewujudkan penegakan hukum yang adil dan efektif bagi tindak pidana korporasi. Tiga hal penting di antaranya adalah: ${ }^{3}$ Pertama, alokasi tanggung jawab atas tindak pidana

\footnotetext{
${ }^{2}$ Indonesia (A), Undang-Undang No. 23 Tahun 1997 tentang Pengelolaan Lingkungan Hidup, LN Tahun 1997 LN No. 68, TLN No. 3699.

3 Brent Fisse dan John Braithwaite, "Corporations, Crime and Accountability", (Cambridge: Cambridge University Press, 1993), hal. 135-136.
} 
korporasi harus didasarkan pada pemahaman bahwa tindakan korporasi bukanlah sekedar jumlah dari tindakan individu-individu di dalam korporasi, tetapi juga dapat merupakan tindakan dari korporasi itu sendiri. Kedua, alokasi tanggung jawab atas tindak pidana korporasi harus mampu mengalokasikan tanggung jawab kepada setiap pihak yang harus bertanggung jawab, baik itu individu, sub unit dari korporasi, korporasi, perusahaan induk, asosiasi industri, atau mereka yang harus mengawasi korporasi seperti akuntan atau bahkan regulator. Ketiga, alokasi tanggung jawab kepada individu harus mampu menghindari kemungkinan dikorbankannya pihak tertentu dalam korporasi sebagai kambing hitam.

Dari uraian di atas terlihat bahwa pertanggungjawaban korporasi dan pertanggungjawaban pribadi memegang peranan penting untuk menjamin adanya akuntabilitas dari korporasi. Persoalannya adalah bagaimana menjadikan sebuah korporasi dan/atau pengurus korporasi bertanggungjawab atas tindak pidana korporasi. Pertanyaan di atas dapat dijawab dengan memperlihatkan bagaimana pertanggungjawaban korporasi berkembang di beberapa negara, dan bagaimana penafsiran tersebut dibandingkan dengan penafsiran dan praktek di Indonesia.

Tulisan ini akan menjelaskan klasifikasi dan sejarah perkembangan pertanggungjawaban korporasi, bagaimana tindak pidana dan pertanggungjawaban korporasi dijelaskan oleh berbagai teori, dan bagaimana pertanggungjawaban korporasi dibedakan dari pertanggungjawaban pribadi pengurus korporasi. Adapun struktur dari tulisan ini adalah sebagai berikut: Pada Bagian 1 akan dipaparkan mengenai pendahuluan. Setelah itu, Bagian 2 akan membahas mengenai tindak pidana dan pertanggungjawaban korporasi dalam hukum lingkungan di Indonesia. Bagian ini tidak hanya menjelaskan mengenai klasifikasi dan sejarah perkembangan pertanggungjawaban korporasi, tetapi juga menjelaskan bagaimana tindak pidana dan pertanggungjawaban korporasi dijelaskan oleh berbagai teori, dan bagaimana pertanggungjawaban korporasi dibedakan dari pertanggungjawaban pribadi pengurus korporasi. Selanjutnya, Bagian 3 akan membahas mengenai tindak pidana korporasi, serta pertanggungjawaban korporasi dan pemimpin/pengurus korporasi menurut UU lingkungan hidup (UU No. 32 Tahun 2009), ${ }^{4}$ serta membandingkannya dengan perumusan pertanggungjawaban dan tindak pidana korporasi menurut UU No. 41 Tahun 1999 tentang Kehutanan, ${ }^{5}$ UU No. 18 Tahun 2013 tentang Pencegahan dan Pemberantasan Perusakan Hutan, ${ }^{6}$ UU No. 39 Tahun 2014 tentang Perkebunan, ${ }^{7}$ dan Rancangan Kitab Undang-

\footnotetext{
${ }^{4}$ Indonesia (B), Undang-Undang No. 32 Tahun 2009 tentang Perlindungan dan Pengelolaan Lingkungan Hidup, LN Tahun 2009 No. 140, TLN No. 5059.

${ }^{5}$ Indonesia (C), Undang-Undang No. 41 Tahun 1999 tentang Kehutanan, LN Tahun 1999 No. 167, TLN No. 3888, sebagaimana telah diubah oleh PERPU No. 1 Tahun 2004 tentang Perubahan atas Undang-Undang Nomor 41 Tahun 1999, LN Tahun 2004 No. 29, TLN No. 4374.

${ }^{6}$ Indonesia (D), Undang-Undang No. 18 Tahun 2013 tentang Pencegahan dan Pemberantasan Perusakan Hutan, LN Tahun 2013 No. 130, TLN No. .

${ }^{7}$ Indonesia (E), Undang-Undang No. 39 Tahun 2014 tentang Perkebunan, LN Tahun 2014 No. 308, TLN No. 5613 .
} 
undang Hukum Pidana (RKUHP) Buku Kesatu. ${ }^{8}$ Bagian ini juga akan mendiskusikan penafsiran dan penerapan pertanggungjawaban korporasi dalam beberapa putusan terkait pencemaran lingkungan di Indonesia. Bagian 4 secara kritis membahas mengenai penerapan pertanggungjawaban korporasi di Indonesia. Bagian 5 akan memaparkan beberapa catatan penutup dari tulisan ini.

\section{Tindak Pidana Korporas serta Pertanggungjawaban Korporasi dan Pemimpin/Pengurus Korporasi}

Menurut de Maglie, secara garis besar pembahasan terkait pertanggungjawaban korporasi dapat dibagi ke dalam tiga persoalan, yaitu: a. pembahasan tentang penentuan organisasi seperti apa yang dapat dimintakan pertanggungjawaban; b. jenis tindak pidana apa yang dianggap dapat dilakukan oleh korporasi; dan c. kriteria apa yang diperlukan untuk mengatribusikan (melekatkan) pertanggungjawaban pidana kepada korporasi. ${ }^{9}$

Terkait pertanyaan organisasi seperti apa yang dapat dimintakan pertanggungjawaban, de Maglie mengemukakan tiga pendekatan untuk menjawab pertanyaan tersebut. Pada pendekatan pertama, semua organisasi dapat bertanggungjawab secara pidana. Tidak ada pembatasan mengenai organisasi seperti apa yang bisa bertanggungjawab. Australia dan Belanda menganut pendekatan yang pertama ini. ${ }^{10}$ Pada pendekatan kedua, hanya organisasi yang secara spesifik ditentukan dalam peraturan perundangundangan lah yang dapat memikul pertanggungjawaban pidana. Amerika Serikat dan Kanada menganut pendekatan yang kedua ini, di mana di dalam peraturan perundang-undangan mereka biasanya ditentukan bahwa yang termasuk ke dalam organisasi yang bertanggungjawab, antara lain, adalah:

Corporations, partnerships, associations, joint stock companies, unions, trusts, pension funds, unincorporated organizations, governments and political subdivisions thereof, and nonprofit organizations. ${ }^{11}$

Pada pendekatan ketiga, hanya organisasi yang berbentuk badan hukum lah yang akan dapat dimintai pertanggungjawaban. Perancis dan Denmark adalah conoth dari negara yang menganut pendekatan ini. ${ }^{12}$

${ }^{8}$ Rancangan KUHP Final, Versi 5 Juni 2015, tersedia pada: <http://reformasikuhp.org/r-kuhp/>, diakses pada bulan Mei 2016.

${ }^{9}$ Cristina de Maglie, Models of Corporate Criminal Liability in Comparative Law, "Washington University Global Studies Law Review”, Vol. 4(3), 2005, hal. 550.

${ }^{10}$ Ibid.

${ }^{11}$ Ibid., hal. 550-551.

${ }^{12}$ Ibid., hal. 551. 
Terkait pertanyaan jenis tindak pidana apa yang dianggap dapat dilakukan oleh korporasi, de Maglie menjelaskan bahwa beberapa negara tidak membedakan jenis tindak pidana ini, dalam arti bahwa setiap tindak pidana yang dilakukan oleh orang dianggap dapat pula dilakukan oleh korporasi. Pendekatan ini dianut oleh, antara lain, Australia, Kanada, Belanda. Namun demikian, ada pula negara, misalnya Perancis, yang menyatakan bahwa korporasi hanya bertanggungjawab apabila disebutkan secara tegas di dalam peraturan perundang-undangan yang dijadikan dasar pemidanaan. Di sisi lain, ada pula negara seperti AS yang membuat sebuah daftar (di dalam the U.S. Sentencing Guidelines) yang berisi tentang tindak pidana apa saja yang dapat dimintakan pertanggungjawabannya kepada korporasi. ${ }^{13}$

Sedangkan terkait pertanyaan kriteria apakah untuk menentukan pertanggungajwaban korporasi, de Maglie membagi pula kriteria tersebut ke dalam tiga pendekatan besar. Pada pendekatan pertama, korporasi bertanggungjawab atas actus reus dan mens rea dari mereka yang bekerja untuk dan atas nama (on behalf of) korporasi. Negara yang menganut pendekatan ini antara lain adalah AS, Belanda, dan Australia. ada pendekatan kedua, korporasi hanya bertanggungjawab apabila yang melakukan tindak pidana adalah pemimpin korporasi. Negara yang menganut pendekatan ini adalah, misalnya, Perancis. Pada pendekatan ketiga, korporasi dianggap bertanggungjawab atas kesalahannya sendiri, misalnya karena adanya kegagalan untuk melakukan pengawasan atau karena adanya budaya di dalam korporasi yang memungkinkan terjadinya tindak pidana. ${ }^{14}$

Terkait kriteria untuk menentukan pertanggungajwaban korporasi, Pieth dan Ivory membagi pula kriteria tersebut ke dalam tiga kelompok yang sama dengan pembagian yang dilakukan oleh de Maglie. Menurut Pieth dan Ivory, pertanggungjawaban korporasi terbentuk dengan tiga kriteria. Pada kriteria pertama, korporasi bertanggungjawab atas tindak pidana yang dilakukan oleh pekerjanya. Dalam hal ini bisa muncul dua kemungkinan. Pertama, korporasi bertanggungjawab secara strict vicarious liability, yaitu tanpa mempedulikan apakah korporasi sudah mencegah atau mengambil langkah untuk merespon tindak pidana tersebut atau tidak. Kedua, korporasi bertanggunggjawab secara qualified vicarious liability, yaitu hanya jika korporasi gagal untuk mengambil langkah yang layak guna mencegah tindak pidana. Pada kriteria kedua, korporasi hanya bertanggungjawab atas perbuatan pemimpin korporasi. Untuk kriteria pertama dan kedua, korporasi bertanggungjawab atas perbuatan seseorang, sehingga pertanggungjawaban ini merupakan pertanggungjawaban turunan (derivative) dari pertanggungjawaban pribadi. Ketiga, korporasi bertanggungjawab dengan cara melihat tindakan kolektif dari orang-orang yang berada di dalamnya baik melalui agregasi, atau melalui organisasi di dalam korporasi yang mendorong terjadinya tindak pidana. Pada kriteria ketiga ini, korporasi bertanggungjawab atas kesalahannya sendiri atau tindak pidana yang

\footnotetext{
${ }^{13}$ Ibid., hal. 551-552.

${ }^{14}$ Ibid., hal. 553-560.
} 
dilakukannya sendiri (corporate's fault atau culpability). ${ }^{15}$ Menurut krieteria ketiga ini, pertanggungjawaban korporasi muncul karena perbuatan korporasi itu sendiri, sehingga pertanggungjawaban korporasi dapat saja muncul tanpa perlu mengaitkannya dengan tindakan dan pertanggungjawaban pidana dari orang-orang di dalam korporasi.

Menurut penulis, selain dari persoalan di atas, satu hal lain yang juga sangat erat kaitannya dengan tindak pidana dan pertanggungjawaban korporasi adalah kriteria apa yang diperlukan untuk meminta pertanggungjawaban dari

${ }^{15}$ Menurut mereka, pertanggungjawaban korporasi muncul dengan jalan:

- "by imputing the corporation with offenses by any corporate agent oremployee - no matter what steps others in the corporation had taken to prevent and respond to the misconduct (strict vicarious liability), or if others had not done enough to prevent the wrongdoing (qualified vicarious liability)

- "by identifying the corporation with its executive bodies and managers and holding it liable for their acts, omissions, and states of mind (identification); and

- "by treating the collective as capable of offending in its own right, either through the aggregated thoughts and deeds of its senior stakeholders (aggregation) or though inadequate organizational systems and cultures (corporate culture, corporate (dis)organization)".

Lihat: Mark Pieth and Radha Ivory, Emergence and Convergence: Corporate Criminal Liability Principles in Overview, dalam: Mark Pieth dan Radha Ivory (eds.), "Corporate Criminal Liability: Emergence, Convergence, and Risk”, (Dordrecht: Springer, 2011), hal. 21-22.

Pembagian yang sedikit berbeda diperlihatkan oleh Gobert, yang tidak membedakan apakah tindak pidana dilakukan oleh seseorang dengan jabatan tinggi di dalam korporasi atau tidak. Menurutnya, kriteria untuk menentukan pertanggungajwaban korporasi ke dalam tiga kelompok, yaitu:

1. "When it orders, aids, abets, counsels, or in any other way facilitates a criminal offence by a person for whom the organization bears responsibility (e.g., one of its directors, officers, employees or agents)

2. "When it fails to prevent a crime by a person for whom the organization bears responsibility; in circumstances where:

a. it had a duty to its employees, consumers or users of its product, or members of the public to prevent harm, and;

b. when it was - or with the exercise of due diligence - should have been, aware of the risks that were presented by a policy or course of action or inaction;

c. when it had the capacity to prevent the violation; and

d. when it was not unreasonable for it do so.

3. "Permits a corporate culture that tolerates, encourages, or fails to discourage crimes; or fails to establish a corporate culture that demands compliance with the law."

Pada kriteria pertama, korporasi bertanggungjawab jika memerintahkan, membantu, mendorong, memberikan nasehat, atau memfasilitasi tindak pidana oleh orang yang bekerja untuknya. Pada kriteria kedua, korporasi juga bertanggungjawab atas tindak pidana seseorang yang bekerja untuknya, jika: a). korporasi memiliki kewajiban untuk mencegah terjadinya bahaya/tindak pidana; b). korporasi menyadari atau dianggap harus menyadari adanya resiko bahaya/tindak pidana yang akan muncul dari kebijakannya atau dari diambilnya atau tidak diambilnya tindakan oleh korporasi; c). korporasi memiliki kapasitas untuk mencegah terjadinya pelanggaran; dan d). tindakan pencegahan oleh korporasi merupakan tindakan yang layak diharapkan darinya. Pada kriteria ketiga, korporasi bertanggungjawab jika terdapat budaya di dalam korporasi yang memberikan toleransi atau mendorong terjadinya tindak pindana, atau jika korporasi gagal untuk membentuk budaya korporasi yang mendorong penaatan terhadap hukum. Lihat: James Gobert (2008), The Evolving Legal Test of Corporate Criminal Liability, dalam: John Minkes dan Leonard Minkes (eds.), “Corporate and White-collar Crime”, (London: Sage Publications Ltd., 2008), hal. 79. 
pemimpin/pengurus korporasi. Menurut penulis, kriteria ini perlu dibahas karena secara teoritis apabila sebuah korporasi bertanggungjawab atas sebuah tindak pidana, belum tentu secara otomatis pengurus korporasi juga menjadi ikut bertanggungjawab. Secara jelas, hal ini dapat dilihat dari pernyataan Sarre bahwa "[i]mposing criminal liability on corporations for regulatory breaches by its senior officers is one thing; imposing personal criminal liability on senior officers simply because their company has committed an offence is quite another". ${ }^{16}$ Dari kutipan ini terlihat bahwa membuat korporasi bertanggungjawab atas perbuatan seseorang tidaklah sama dengan membuat seseorang bertanggungjawab atas perbuatan korporasi.

Dalam tulisan ini, penulis akan membahas kriteria untuk menentukan pertanggungjawaban korporasi di dalam Bagian 2.1. Selain itu, penulis akan membahas persoalan pertanggungjawaban pemimpin/pengurus korporasi sebagai bagian tersendiri yang terpisah dari pertanggungjawaban korporasi pada Bagian 2.2.

\section{Teori Pertanggungjawaban Korporasi}

\section{a. Pertanggungjawaban Pengganti (Vicarious Liability/ Respondeat Superior)}

Pertanggungjawaban pengganti (disebut dengan vicarious liability atau respondeat superior) merupakan salah satu bentuk pertanggungjawaban korporasi yang paling banyak diterapkan di berbagai negara. Dalam pertanggungjawaban ini, korporasi bertanggungjawab atas tindak pidana yang dilakukan oleh seorang pekerjanya, tanpa melihat status atau kedudukan orang tersebut di dalam korporasi. Dalam hal ini, Feinberg sebagaimana dikutip oleh Harding, menyatakan bahwa vicarious liability adalah pertanggungjawaban kolektif, di mana organisasi bertanggungjawab atas perbuatan dari anggotanya. ${ }^{17}$ Perlu dicatat bahwa pertanggungjawaban pengganti ini dapat dikenakan baik kepada korporasi (corporate vicarious liability), maupun kepada pemimpin/ pengurus korporasi (individual vicarious liability). ${ }^{18}$ Dalam pembahasan pada bagian ini, yang dimaksud dengan pertanggungjawaban pengganti adalah dalam arti corporate vicarious

\footnotetext{
16 Rick Sarre, Penalising Corporate 'Culture': The Key to Safer Corporate Activity?, dalam: James Gobert dan Ana-Maria Pascal (eds.), "European Developments in Corporate Criminal Liability", (London: Routledge, 2011), hal. 86.

${ }^{17}$ Feinberg menyatakan: "[c]ollective liability, as I shall use the term, is the vicarious liability of an organized group (either a loosely organized or impermanent collection or a corporate institution) for the actions of its constituent members ...". Lihat: Christopher Harding, "Criminal Enterprise: Individuals, Organisations and Criminal Responsibility”, (Portland: Willan Publishing, 2007), hal. 87.

18 James Gobert, Squaring the Circle: The relationship between Individual and Organizational Fault, dalam: James Gobert dan Ana-Maria Pascal (eds.), "European Developments in Corporate Criminal Liability”, (London: Routledge, 2011), hal. 141-143.
} 
liability; sedangkan individual vicarious liability akan dibahas pada Bagian 2.2.

Salah satu negara yang mempraktekkan pertanggungjawaban pengganti ini adalah AS. Berdasarkan penelusuran Webb, dkk. terhadap beberapa putusan di AS, korporasi dapat bertanggungjawab atas tindak pidana yang dilakukan oleh: a). orang yang secara langsung terkait dengan korporasi, seperti direktur, pengurus, maupun pegawai; b). anak perusahaan (subsidiaries); dan c). kontraktor dari korporasi (independent contractor). ${ }^{19}$

Adapun syarat yang digunakan oleh pengadilan AS dalam menentukan pertanggungjawaban pengganti adalah bahwa tindak pidana dilakukan oleh pelaku di dalam ruang lingkup kewenangannya (scope of authority/employment) dan bahwa tindak pidana tersebut dilakukan untuk menguntungkan korporasi (for the benefit of the corporation). Terkait hal ini, Gobert menyatakan bahwa kriteria yang penting untuk dibuktikan di dalam vicarious liability adalah bahwa pada saat melakukan tindak pidananya, pelaku sedang mengerjakan urusan korporasi dan bahwa tindak pidana itu dilakukan untuk mewujudkan kepentingan korporasi. ${ }^{20}$ Dengan demikian, pertanggungjawaban korporasi muncul dari dilekatkannya pertanggungjawaban untuk perbuatan seseorang kepada korporasi.

Lebih jauh lagi Webb, dkk. menyimpulkan bahwa di dalam beberapa kasus, lingkup kewenangan (scope of authority) tidaklah selalu mensyaratkan bahwa korporasi benar-benar mengizinkan pegawainya untuk melakukan tindak pidana. Sebaliknya, cukup dibuktikan saja bahwa ketika pegawai melakukan tindak pidananya, ia sedang menjalankan tugas dan wewenangnya yang biasa dikerjakannya. Sepanjang perbuatan pelaku dianggap termasuk ke dalam lingkup fungsi pekerjaannya, maka "scope of authority" dianggap terbukti dan korporasi bertanggungjawab, meskipun perbuatan pelaku tersebut misalnya bertentangan dengan kebijakan tertulis dari korporasi. ${ }^{21}$

Terkait unsur menguntungkan korporasi, Webb, dkk. menyatakan bahwa persyaratan ini dipenuhi apabila setidaknya sebagian tujuan dari pelaku adalah untuk menguntungkan korporasi. Apabila perbuatan pelaku sepenuhnya bertujuan untuk menguntungkan dirinya sendiri, atau apabila korporasi adalah korban dari perbuatan pelaku (misalnya terjadi penggelapan uang korporasi),

${ }^{19}$ Lihat pembahasan dan kasus-kasus yang menyertainya dalam: Dan K. Webb, Steven F. Molo dan James F. Hurst, Understanding and Avoiding Corporate and Executive Criminal Liability, "The Business Lawyer", Vol. 49(2), February 1994, hal. 622-624.

${ }^{20}$ Menurut Gobert, "[u]nder a test of vicarious liability, the link between a company's criminal liability and an individual's crime is the fact that at the time of the offence the offender was engaged in the company's business and pursuing corporate goals... Corporate liability results from imputing to the company the crime of the individual." Lihat: James Gobert (2008), Op. Cit., hal. 64.

${ }^{21}$ Dan K. Webb, Steven F. Molo dan James F. Hurst, Op. Cit., hal. 620-621. 
maka pelaku bertanggungjawab secara pribadi. Salah satu contoh yang dikemukakan oleh Webb, dkk. untuk menjelaskan unsur menguntungkan korporasi adalah putusan Pengadilan Banding 4th Circuit dalam kasus United States v. Automated Medical Laboratories. Dalam kasus ini, seorang kepala bagian memerintahkan bawahannya memalsukan laporan perusahaan terkait ketaatan perusahaan terhadap regulasi FDA (Food and Drug Administration). Pemalsuan tersebut dimaksudkan untuk menutupi adanya ketidaktaatan dari perusahaan tersebut. Atas tindakan pemalsuan tersebut, perusahaan didakwa melakukan pelanggaran peraturan perundang-undangan. Dalam kasus ini, perusahaan berdalih bahwa perbuatan kepala bagian tersebut dilakukan untuk kepentingannya sendiri, yaitu agar ia memperoleh promosi karier di dalam perusahaan. Pengadilan menolak dalih ini dengan alasan bahwa kepentingan pribadi pelaku tersebut tergantung dari keuntungan yang diperoleh perusahaan, dalam hal ini tergantung pada penaatan perusahaan terhadap regulasi FDA. ${ }^{22}$

Lebih jauh lagi, perlu pula diutarakan di sini bahwa tindak pidana yang bertentangan dengan program/kebijakan perusahaan tidak selalu berarti bahwa perbuatan tersebut berada di luar lingkup kerja, sehingga dapat membebaskan perusahaan dari pertanggungjawaban. Dalam hal ini, Pengadilan Banding 2nd Circuit dalam United States v. Twentieth Century Fox Film Corp. menolak dalih perusahaan yang menyatakan bahwa perbuatan pelaku (pegawainya) merupakan hal yang secara tegas dilarang oleh perusahaan melalui program penaatan mereka. Pandangan Pengadilan tersebut dapat dilihat dalam kutipan berikut: ${ }^{23}$

Fox argues, however, that even if its branch manager willfully violated the decree, any violation by the corporation was not willful in view of the extensive program Fox adopted to encourage its employees to comply with the decree. At trial, Fox sought to introduce evidence regarding its compliance program, but Judge Palmieri refused to admit it.

We agree with the District Court that Fox's compliance program, however extensive, does not immunize the corporation from liability when its employees, acting within the scope of their authority, fail to comply with the law and the consent decree. It is settled law that a corporation may be held criminally responsible for antitrust violations committed by its employees or agents acting within the scope of their authority.... We see no

${ }^{22}$ Ibid., hal. 621.

${ }^{23}$ United States v. Twentieth Century Fox Film Corp., 882 F.2d 656 (2d Cir 1989), hal. 22. 
reason to establish higher standards of proof for corporate violations of antitrust consent decrees than for violations of the antitrust laws themselves.

Persyaratan yang hampir sama dengan yang kriteria pertanggungjawaban pengganti di AS juga dianut oleh Australian Criminal Code. Sebagaimana dipaparkan oleh de Maglie, syarat yang dianut oleh undang-undang ini adalah adanya lingkup kerja (scope of employment) dan maksud untuk menguntungkan korporasi (intent to benefit the corporation). Mengenai lingkup kerja, de Maglie menyatkan bahwa pengadilan di Australia memperluas makna lingkup kerja sehingga tidak hanya meliputi perbuatan yang secara terbuka, diam-diam, atau tersirat disetujui oleh dewan direksi dari perusahaan, tetapi juga semua perbuatan yang terkait dengan pola perbuatan seseorang sebagai pegawai perusahaan tersebut. Sedangkan dalam hal unsur dengan maksud menguntungkan perusahaan, pengadilan Australia tidaklah mensyaratkan bahwa keseluruhan tujuan perbuatan pelaku adalah untuk keuntungan perusahaan. Meskipun pelaku memiliki maksud untuk menguntungkan diri sendiri, apabila di dalam perbuatannya juga termuat maksud untuk menguntungkan korporasi, maka unsur dengan menguntungkan perusahaan telah dianggap terpenuhi. ${ }^{24}$

Lebih jauh lagi, berdasarkan hasil perbandingan, Stessens mengutarakan bahwa selain AS dan Australia, kriteria menguntungkan korporasi juga menjadi syarat pertanggungjawaban korporasi di Perancis, Jerman, Belanda, dan Kanada. Sedangkan di Inggris, syarat menguntungkan korporasi ini tidak selalu diperlukan. Dalam hal ini, Stessens merujuk pada kasus DPP v. Kent and Sussex Contractors Ltd., di mana korporasi bertanggungjawab atas perbuatan pegawai, meskipun korporasi tersebut merupakan korban dari perbuatan tersebut. Tentu saja hal ini sedikit mengherankan, sehingga bahkan di Inggris sendiri pun putusan di atas memperoleh kritik yang tajam. ${ }^{25}$

Sementara itu, Keulen dan Gritter mengungkapkan bahwa pengadilan di Belanda menggunakan kriteria yang berbeda-beda terkait pertanggungjawaban pengganti. Berdasarkan rangkuman kriteria yang dibuat oleh kedua pengarang ini, korporasi bertanggungjawab apabila: a). tindak pidana diduga dilakukan oleh seseorang yang bekerja untuk korporasi, baik atas dasar hubungan kerja yang formal maupun tidak; b). tindak pidana yang dilakukan merupakan bagian dari kegiatan normal korporasi sehari-hari; c). korporasi memperoleh keuntungan dari tindak pidana yang

\footnotetext{
${ }^{24}$ Cristina de Maglie, Op. Cit., hal. 554.

${ }^{25}$ Guy Stessens, Corporate Criminal Liability: A Comparative Perspective, "The International and Comparative Law Quarterly", Vol. 43(3), 1994, hal. 514-515.
} 
dilakukan; d). korporasi memiliki kekuasaan terhadap tindak pidana, dan sekaligus menerima tindak pidana tersebut. ${ }^{26}$

Khusus mengenai kriteria terakhir, Stessens menyatakan bahwa kekuasaan dan penerimaan korporasi berasal dari kriteria yang dipakai di dalam kasus kawat besi (IJzerdraad) tahun 1954. Dalam kasus ini, Hoge Raad menyatakan bahwa korporasi bertanggungjawab atas perbuatan pegawainya apabila: a). korporasi memiliki kekuasaan untuk menentukan perbuatan pegawainya, dan b). perbuatan pegawai ini termasuk ke dalam perbuatan yang biasanya diterima oleh korporasi, sehingga dianggap sebagai bagian dari pelaksanaan urusan korporasi yang biasa dilakukan. ${ }^{27}$ Dengan demikian, putusan IJzerdraad menghasilkan dua kriteria bagi penentuan pertanggungjawaban korporasi, yaitu adanya kekuasaan (power) dan penerimaan (acceptance). Kedua kriteria inilah yang kemudian masuk ke dalam peraturan perundang-undangan dalam Penjelasan Pasal 118 UU No. 32 Tahun 2009 tentang Perlindungan dan Pengelolaan Lingkungan Hidup.

\section{b. Teori Identifikasi (Theory of Identification)}

Teori identifikasi adalah teori pertanggungjawaban korporasi yang dianut di Inggris. Berdasarkan teori ini, korporasi bertanggungjawab atas tindak pidana yang dilakukan oleh pengurus/ pemimpin korporasi. Menurut Gobert, teori identifikasi adalah salah satu varian dari pertanggungjawaban pengganti. ${ }^{28}$ Dengan demikian, syarat dari pertanggungjawaban pengganti, yaitu bahwa tindak pidana termasuk ke dalam lingkup kerja dan menguntungkan korporasi, haruslah terpenuhi. Namun demikian, dari tiga kasus awal yang menerapkan teori identifikasi yang dikemukakan oleh Gobert sendiri terlihat bahwa pelaku justru bertindak merugikan korporasi. Dalam kasus DPP $v$ Kent and Sussex Contractors Ltd., dinyatakan bahwa pikiran dari korporasi dapat ditemukan dalam pikiran pegawai

${ }^{26}$ Keulen dan Gritter, menyatakan bahwa kriteria tersebut adalah:

- "The act or an omission was allegedly committed by someone who works for the corporation, whether under a formal contract of employment or not.

- "The impugned act or omission was part of the everyday "normal business" of the corporation.

- "The corporation profited from the relevant conduct.

- "The allegedly criminal course of conduct was at the "disposal" of the corporation and the corporation "accepted" the conduct, that acceptance including the failure to take reasonable care to prevent the act or omission from being carried out."

Lihat: Berend F. Keulen and Erik Gritter, Corporate Criminal Liability in the Netherlands, dalam Mark Pieth dan Radha Ivory (eds.), "Corporate Criminal Liability: Emergence, Convergence, And Risk", (Dordrecht: Springer, 2011), hal. 183.

${ }^{27}$ Guy Stessens, Op. Cit., hal. 511.

${ }^{28}$ James Gobert (2008), Op. Cit., hal. 67. 
yang diberikan wewenang untuk berbicara dan bertindak atas nama korporasi. Jika pegawai tersebut memiliki niat untuk melakukan penipuan, maka korporasi pun dianggap memiliki niat untuk menipu. Dalam kasus $R$ v ICR Haulage Ltd. seorang direktur dari perusahaan dan perusahaan itu sendiri, bersama-sama dengan sembilan orang pegawai lainnya, didakwa melalukan konspirasi tindak pidana penipuan. Dalam kasus ini pun pengadilan menegaskan kembali bahwa apa yang menjadi niat, pengetahuan, dan kepercayaan dari pemimpin korporasi dapat dianggap sebagai niat, pengetahuan, dan kepercayaan dari korporasi itu sendiri. Sementara itu, dalam kasus Moore v Bresler Ltd., seorang sekretaris dan korporasi didakwa atas pemalsuan dokumen. Dalam kasus ini, sekretaris sebenarnya melalukan penjualan produk perusahaan dengan tujuan untuk memperkaya diri sendiri. Untuk menutupi perbuatannya, sekretaris tersebut membuat laporan pajak palsu kepada pemerintah, di mana penjualan yang dilakukannya tidaklah termasuk ke dalam laporan tersebut. Meskipun dalam kasus ini korporasi adalah korban, namun dalam kasus ini pun korporasi bertanggungjawab atas perbuatan pelaku. ${ }^{29}$

Ketiga kasus di atas menunjukkan bahwa apabila digunakan vicarious liability, maka korporasi akan bebas dari pertanggungjawaban. Namun karena dalam kasus ini pelaku adalah pengurus/pemimpin korporasi, maka perbuatan mereka dianggap masih berada di dalam lingkup kerja/kewenangannya, sehingga korporasi tetaplah bertanggungjawab.

Selanjutnya, putusan pengadilan Inggris yang dianggap paling mewakili teori identifikasi adalah putusan Tesco Supermarkets Ltd. $v$ Nattrass. Dalam putusan ini, untuk menjelaskan pertanggungjawaban korporasi, Lord Reid merujuk pada pandangan Lord Denning yang menganalogikan perbedaan antara pegawai biasa dengan pengurus/pemimpin korporasi seperti perbedaan antara tangan dan pikiran/otak manusia. Menurut analogi ini, sama seperti perbuatan manusia dikendalikan oleh kehendak pikiran/otak, maka perbuatan korporasi dikendalikan oleh kehendak dari pemimpin/pengurusnya. Dalam hal ini, Lord Denning, sebagaimana dikutip oleh Gobert, menyatakan: ${ }^{30}$

A company may in many ways be likened to the human body. It has a brain and nerve centre which controls what it does. It also has hands which hold the tools and act in accordance with directions from the centre. Some of the people in the company are mere servants and agents who are nothing more than hands to do the work ... Others are

${ }^{29}$ Ibid., hal. 64-65. Lihat pula pembahasan ketiga kasus tersebut dalam: Harvey Yarosky, The Criminal Liability of Corporations, "McGill Law Journal”, Vol. 10(2), 1964, hal. 144-147.

${ }^{30}$ James Gobert (2008), Op. Cit., hal. 66. 
directors and managers who represent the directing mind and will of the company and control what it does. The state of mind of those managers is the state of mind of the company.

Uraian di atas memperlihatkan bahwa untuk menentukan apakah perbuatan seseorang dapat diidentifikasi sebagai perbuatan korporasi, teori identifikasi menggunakan gambaran keterkaitan antara alam pikiran dengan gerak tubuh manusia. Dalam hal ini, alam pikiran ini seringkali digambarkan melalui istilah "directing mind" (pikiran yang mengarahkan perbuatan), "directing will" (kehendak yang mengarahkan perbuatan), "ego centre" (pusat ego), atau "control centre" (pusat pengaturan). Alam pikiran ini yang dianggap akan menggerakan tubuh manusia. Dalam hal ini, "a corporate 'body' shall not be punished for a serious offence when its corporate 'hands' act without direction from its 'mind", korporasi secara keseluruhan tidaklah bertanggung jawab atas perbuatan yang dilakukan oleh 'tangan' korporasi apabila perbuatan 'tangan' ini dilakukan tanpa adanya arahan dari 'pikiran' korporasi. ${ }^{31}$ Seseorang akan dianggap sebagai "directing mind/will", kehendak atau pikiran yang menentukan dalam korporasi, apabila orang tersebut adalah "superior agent" (pegawai tinggi), "responsible agent" (pegawai yang bertanggungjawab), "important official" (pegawai yang penting), "primary agent" (pegawai utama), atau "top management". ${ }^{32}$

Untuk menentukan siapa yang dianggap sebagai pikiran/organ korporasi atau pegawai penting/pimpinan dari korporasi, dan siapa yang hanya hanya merupakan tubuh atau agent (pegawai pelaksana) dari korporasi, maka pengujian biasanya dilakukan dengan menentukan apakah pelaku kegiatan termasuk ke dalam organ primer korporasi atau bukan. Adapun organ primer korporasi sering kali dijelaskan dengan merujuk pada dokumen resmi korporasi yang menentukan hierarki korporasi dan organ utama mana yang dianggap sebagai wakil dari korporasi. ${ }^{33}$

Stern mengkritik pengujian berdasarkan dokumen tersebut. Menurutnya, dalam korporasi modern, yang disebut pimpinan atau organ utama atau badan yang mewakili ini sering kali berfungsi hanya untuk memberikan persetujuan atas sebuah perbuatan yang dilakukan oleh agent atau badan lain yang sering kali bertindak otonom. ${ }^{34}$ Artinya, jika perbuatan pemimpin tidak lebih dari sekedar

${ }^{31}$ Yedidia Z. Stern, Corporate Criminal Personal Liability: Who is the Corporation?, "Journal of Corporation Law”, Vol. 13(1), 1987, hal. 132.

32 Ibid., hal. 134.

${ }^{33}$ Ibid., hal. 132-133.

${ }^{34}$ Ibid., hal. 132. 
memberikan persetujuan, maka perbuatan yang dilakukan oleh pelaku akan gagal untuk dianggap sebagai perbuatan dari korporasi. Untuk mengatasi hal ini, Stern mengusulkan adanya pengujian melalui dua tahapan. Pada tahap pertama dilakukan pengujian atas dasar fungsi. Dalam hal ini akan dilihat apakah perbuatan yang dilakukan menunjukkan fungsi "sebagai" korporasi (dan bukannya fungsi "untuk" korporasi) dan apakah perbuatan tersebut sesuai dengan lingkup kerja pelaku. Melalui pengujian ini, perbuatan dari seorang pemimpin korporasi tetap tidak bisa dianggap sebagai perbuatan korporasi jika perbuatan tersebut merupakan perbuatan ultra vires (melampaui wewenang), atau merupakan perbautan yang intra vires (tidak melampaui wewenang) tetapi dianggap tidak dapat diatribusikan kepada korporasi sehingga tidak berfungsi sebagai perbuatan sebagai korporasi. Jika jawaban atas pengujian di atas adalah positif, maka dilanjukan dengan pengujian tahap kedua, yaitu pengujian atas dasar hierarki: apakah pelaku memiliki tempat yang tinggi di dalam hierarki korporasi. Perbuatan pelaku akan dianggap identik dengan perbuatan korporasi hanya jika pelaku memiliki jabatan yang tinggi di dalam korporasi. ${ }^{35}$

\section{c. Teori Agregasi (Aggregaton Theory)}

Berdasarkan teori ini, pertanggungjawaban korporasi didasarkan pada penjumlahan (aggregation) dari pikiran (state of mind) atau kesalahan (culpability) dari tiap individu yang mewakili korporasi. Agregasi di sini tidak berarti benar-benar menjumlahkan semua pikiran, tetapi lebih pada membandingkan pikiran satu orang dengan orang lainnya. Teori ini dianut di AS, dalam putusan Pengadilan Banding $1^{\text {st }}$ Circuit dalam United States v. Bank of New England (1987). Sebagai tindak lanjut dari Currency Transaction Reporting Act [31 U.S.C. $\S \S$ 5311-22 (1982)], Departeman Keuangan (Department of Treasury) AS mengeluarkan peraturan yang mewajibkan bank untuk melakukan laporan (Currency Transaction Reports, CTRs) dalam waktu 15 hari atas transaksi di atas US\$ 10.000. Aturan tersebut menyatakan: "[e]ach financial institution, other than a casino shall file a report of each deposit, withdrawal, exchange of currency or other payment or transfer, by, through, or to such financial institution, which involves a transaction in currency of more than \$ 10,000.” [31 C.F.R. § 103.22 (a)(1)(1986)]. Kegagalan melaporkan transaksi tersebut merupakan tindak pidana berdasarkan Currency Transaction Reporting Act yang menyatakan: " $[a]$ person willfully violating this subchapter or a regulation prescribed under this subchapter ..., while violating another law of the United States or as part of a pattern of illegal activity involving transactions of

${ }^{35}$ Ibid., hal. 140, dan 142-143. 
more than \$100,000 in a 12-month period, shall be fined no more than \$ 500,000, imprisoned for not more than 5 years, or both."[31 U.S.C. $\S 5322(b)]$. Dalam kasus tersebut, terdapat pegawai Bank yang mengetahui adanya kewajiban memberikan laporan tersebut. Namun pegawai tersebut tidak mengetahui adanya transaksi di atas US\$ 10.000. Sementara itu, terdapat pegawai Bank yang mengetahui adanya transaksi di atas US\$ 10.000 , tetapi ia tidak mengetahui adanya kewajiban memberkan laporan atas transaksi tersebut. Akibatnya, tidak ada pegawai Bank yang memberikan laporan transaksi tersebut.

Pengadilan tingkat pertama dalam kasus tersebut memerintahkan kepada juri agar pengetahuan dan tindakan individu pegawai Bank dapat dilekatkan pada pengetahuan dan tindakan Bank. Lebih dari itu, pengadilan membuka kemungkinan diterapkannya pengetahuan kolektif pegawai untuk menentukan pengetahuan dari Bank. Menurut pengadilan:

If Employee A knows one facet of the currency reporting requirement, $B$ knows another facet of it, and $C$ a third facet of it, the bank knows them all. So if you find that an employee within the scope of his employment knew that CTRs had to be filed, even if multiple checks are used, the bank is deemed to know it. The bank is also deemed to know it if each of several employees knew a part of that requirement and the sum of what the separate employees knew amounted to knowledge that such a requirement existed. $^{36}$

Dari kutipan di atas terlihat bahwa berdasarkan teori agregasi, maka meskipun perbuatan satu-dua individu tidaklah memenuhi tindak pidana, tetapi korporasi dapat tetap bertanggungjawab apabila tindakan dari individu-individu secara kolektif tetap memenuhi tindak pidana. Tentu saja sepanjang individu-individu tersebut bekerja di dalam lingkup kerja mereka. Dengan demikian, dalam

${ }^{36}$ United States v. Bank of New England, N.A., 821 F.2d 844 (1st Cir 1987), hal. 855.

Pengadilan tersebut menjelaskan pengetahuan kolektif sebagai berikut:

Pengadilan kemudian memberikan penjelasan mengenai pengetahuan kolektif, sebagai berikut:

A collective knowledge instruction is entirely appropriate in the context of corporate criminal liability...The acts of a corporation are, after all, simply the acts of all of its employees operating within the scope of their employment. The law on corporate criminal liability reflects this.... Similarly, the knowledge obtained by corporate employees acting within the scope of their employment is imputed to the corporation.... Corporations compartmentalize knowledge, subdividing the elements of specific duties and operations into smaller components. The aggregate of those components constitutes the corporation's knowledge of a particular operation. It is irrelevant whether employees administering one component of an operation know the specific activities of employees administering another aspect of the operation."

Lihat: United States v. Bank of New England, N.A., hal. 856. 
United States v. Bank of New England, apa yang tidak diketahui oleh individu pegawai, tetaplahlah harus diketahui oleh Bank.

Atas dasar inilah maka Gobert berpendapat bahwa teori agregasi merupakan jembatan ke arah pertanggungjawaban berdasarkan kesalahan korporasi sendiri. Hal ini dikarenakan pada satu sisi teori agregasi masihlah didasarkan pada perbuatan pegawai, sehingga masih terkait dengan vicarious liability. Namun pada sisi lain, perbuatan pegawai ini tidaklah dipandang sebagai perbuatan oleh satu individu. Artinya, teori agregasi tidaklah mensyaratkan adanya tindak pidana yang sempurna dari satu individu. Karena itulah maka Gobert menyatakan bahwa dalam teori agregasi sebuah korporasi dapat tetap bertanggungjawab meskipun tidak ada satu orang pegawai pun yang telah melakukan tindak pidana. Dalam hal ini, maka pertanggungjawaban korporasi bukanlah merupakan turunan dari tindak pidana seseorang, tetapi merupakan hasil dari kesalahan korporasi itu sendiri. ${ }^{37}$

\section{d. Teori Model Organisasi}

De Maglie menerangkan bahwa berdasarkan model organisasi, korporasi dapat dimintakan pertanggungjawaban karena adanya kulpabilitas dari korporasi. Menurut de Maglie, terdapat empat kemungkinan untuk menjerat korporasi berdasarkan teori ini, yaitu: adanya kebijakan korporasi (corporate policy), adanya budaya korporasi (corporate culture), adanya kesalahan korporasi dalam pencegahan (preventative fault), dan adanya kesalahan korporasi dalam merespon tindak pidana (reactive corporate fault). ${ }^{38}$

Menurut teori Corporate Policy, korporasi bertanggunggung jawab jika tindak pidana muncul karena adanya kebijakan korporasi sendiri yang termasuk kebijakan ilegal. Misalnya kebijakan yang memaksa atau mengizinkan dilakukannya tindak pidana. Pada sisi lain, korporasi dapat pula bertanggungjawab jika tindak pidana terjadi karena adanya kebijakan korporasi yang meskipun legal tetapi dianggap memberikan dorongan bagi terjadinya tindak pidana. Misalnya, adanya toleransi terhadap tindak pidana atau secara sistematis menutup mata atas tindak pidana yang terjadi. ${ }^{39}$

Dalam teori Corporate Culture, korporasi bertanggungjawab karena dianggap memiliki budaya yang mendorong atau memberikan toleransi pada tindak pidana, atau dianggap gagal untuk membangun budaha yang mendorong adanya penaatan. Teori ini berkembang karena di dalam berbagai tindak pidana, struktur atau budaya di dalam korporasi sangatlah berpengaruh. Hal ini misalnya diutarakan

\footnotetext{
${ }^{37}$ James Gobert (2008), Op. Cit., hal. 71.

${ }^{38}$ Cristina de Maglie, Op. Cit., hal. 558.

${ }^{39}$ Ibid.
} 
oleh Punch. Menurutnya, budaya, struktur, sistem penghargaan, sistem rekruitmen, hiearki, pembagian kerja, kepemimpinan, pengambilan keputusan, maupun sistem pertanggungjawaban di dalam korporasi telah mempengaruhi perbuatan individu-individu sehingga cocok dengan perbuatan secara kolektif. Karena itulah maka, menurut Punch, "the organizational component is crucial to corporate crime - no organization, no crime". ${ }^{40}$

Sementara itu, de Maglie mengutarakan bahwa di dalam teori budaya korporasi, korporasi bertanggungjawab atas dasar: a). adanya kebijakan yang secara tersurat maupun tersirat memaksa, mendorong, mengizinkan, atau memberikan toleransi atas tindak pidana yang dilakukan; b). adanya budaya yang mengarahkan, mendorong, atau memberikan toleransi pada dilakukannya tindak pidana; c). adanya kegagalan untuk mengerapkan program penaatan atau untuk melaksanakan upaya pencegahan terhadap tindak pidana; dan d). adanya kegagalan untuk mengambil tindakan pencegahan guna merespon tindak pidana yang dilakukan. ${ }^{41}$

Australia adalah salah satu negara yang menganut teori budaya korporasi. Dalam hal ini, negara bagian Australian Capital Territories (ACT) menegaskan di dalam Criminal Act 2002 mengenai budaya korporasi sebagai dasar pertanggungjawaban korporsi. Section 51 dari UU ini memperlihatkan bahwa apabila tindak pidana memerlukan adanya kesengajaan, pengetahuan, atau kelalaian sebagai elemen dari kesalahan (fault), maka elemen kesalahan tersebut dapat diterapkan kepada korporasi apabila korporasi secara tersurat, tersirat, atau diam-diam mengizinkan (authorize atau permit) dilakukannya tindak pidana. Sementara itu, tindakan "mengizinkan" (authorization atau permission) ditunjukkan antara lain: dengan membuktikan adanya budaya korporasi yang mengarahkan, mendorong, memberikan toleransi, atau mengarahkan pada ketidaktaatan; atau dengan membuktikan bahwa korporasi telah gagal membangun dan memelihara budaya yang mewajibkan adanyaa penaatan. ${ }^{42}$

\footnotetext{
${ }^{40}$ Maurice Punch, The Organizational Component in Corporate Crime, dalam: James Gobert dan Ana-Maria Pascal (eds.), "European Developments in Corporate Criminal Liability", (London: Routledge, 2011), hal. 103.

${ }^{41}$ Cristina de Maglie, Op. Cit., hal. 560.

${ }^{42}$ Criminal Act 2002, sebagaimana dikutip oleh Gobert, menyatakan:

(1). "If intention, knowledge or recklessness is a fault element in relation to a physical element of an offence that may be committed by a company, that fault element must be attributed to a body corporate that expressly, tacitly or impliedly authorized or permitted the commission of the offence.

(2). "The means by which such an authorization or permission may be established include ...

c). proving that a corporate culture existed within the body corporate that directed, encouraged, tolerated or led to non-compliance with the relevant provision; or
} 
Berdasarkan teori Preventive Fault, tanggung jawab korporasi muncul ketika korporasi dianggap gagal untuk memasukkan atau menerapkan sistem internal yang layak untuk mencegah dilakukannya tindak pidana. Dalam hal ini, pertanggungjawaban korporasi muncul karena korporasi tersebut dianggap gagal mengambil langkah yang layak untuk mencegah atau mendeteksi adanya tindak pidana. ${ }^{43}$ Salah satu bentuk dari langkah pencegahan yang layak misalnya adalah dikembangkan dan diterapkannya program internal dari korporasi untuk menjamin adanya penaatan terhadap hukum.

Teori keempat dari Model Organisasi adalah teori kesalahan reaktif korporasi (reactive corporate fault), sebagaimana dikembangkan oleh Fisse dan Braithwaite. ${ }^{44}$ Berdasarkan teori ini, kesalahan korporasi muncul apabila korporasi dianggap gagal untuk mengambil tindakan pencegahan atau tindakan korektif sebagai reaksi atas tindak pidana (actus reus) yang dilakukan oleh personil korporasi. Menurut kedua pengarang ini, yang perlu dipertimbangkan bukanlah apakah korporasi memiliki kebijakan untuk menaati hukum atau tidak, tetapi apakah korporasi melakukan tindakan disiplin internal, reformasi struktural, dan kompensasi sebagai reaksi atas dilakukannya actus reus oleh pegawainya. ${ }^{45}$ Berdasarkan teori ini maka terdapat dua jenis kesalahan. Kesalahan awal (initial fault) adalah tindak pidana yang dilakukan oleh pegawai, sedangkan kesalahan reaktif (reactive fault) adalah kegagalan untuk mengambil tindakan yang seharusnya guna mengoreksi kesalahan awal. Menurut Fisse dan Braithwaite, meskipun bukti tentang kesalahan awal sering kali sulit didapatkan, akan tetapi bukti tentang kesalahan reaktif mudah untuk diperoleh (karena terkait dengan reasksi pasca terjadinya tindak pidana oleh pegawai). ${ }^{46}$ Lebih dari itu, menurut penulis, apabila pertanggungjawaban korporasi atas kesalahan awal dapat digolongkan sebagai pertanggungjawaban korporasi atas perbuatan seseorang (sehingga pertanggungjawaban korporasi adalah turunan dari pertanggungjawaban pribadi), maka pertanggungjawaban korporasi atas kesalahan reaktif lebih merupakan pertanggungjawaban korporasi atas kesalahannya sendiri.

d). proving that the body corporate failed to create and maintain a corporate culture that required compliance with the relevant provision."

Lihat: James Gobert (2011), Op. Cit., hal. 145. Lihat pula: Rick Sarre, Op. Cit., hal. 89-90.

${ }^{43}$ Cristina de Maglie, Op. Cit., hal. 559.

${ }^{44}$ Perlu diperhatkan di sini bahwa oleh Sjahdeini, teori ini dianggap sebagai teori yang berdiri sendiri dan terpisah dari teori budaya korporasi. Lihat: Sutan Remy Sjahdeini, "Pertanggungjawaban Pidana Korporasi”, cet. II (Jakarta: Grafiti Press, 2007), hal. 113-117.

${ }^{45}$ Brent Fisse dan John Braithwaite (1993), Op. Cit., hal. 48. Lihat pula: Brent Fisse dan John Braithwaite (1988), The Allocation of Responsibility for Corporate Crime: Individualism, Collectivism and Accountability, Sydney Law Review, Vol. 11, 1988, hal. 505-506.

${ }^{46}$ Brent Fisse dan John Braithwaite (1993), Op. Cit., hal. 162. 
Rangkuman dari model pertanggungjawaban korporasi dapat dilihat pada Tabel 1 dari Lampiran tulisan ini.

\section{Pemidaan Korporasi dan Pemimpin/Pengurus Korporasi}

Di banyak negara, pemimpin/pengurus korporasi dapat dijatuhi pidana secara sendiri atau secara bersama-sama dengan korporasi, atas sebuah tindak pidana. Stessens menyatakan bahwa di Perancis, Belanda, Inggris dan Wales, serta Kanada pemidaan pemimpin/pengurus korporasi ini dapat diterapkan bersama-sama dengan pertanggungjawaban korporasi. Sementara itu, di Belgia, yang terjadi nayalah pemidanaan bagi pemimpin/pengurus korporasi. ${ }^{47}$ Selain itu, Anderson menambahkan beberapa negara yang juga memungkinkan dijatuhkannya pidana pada pada pemimpin/pengurus koporasi secara sendiri, yaitu: China, Hong Kong, Malaysia, Korea Selatan, dan Afrika Selatan. ${ }^{48}$

Menurut Gobert, pertanggungjawaban pemimpin/pengurus korporasi dianggap perlu jika korporasi hanya dijadikan alat bagi individu pemimpin/pengurus untuk melakukan tindak pidana. Pada sisi lain, Gobert juga menambahkan bahwa pertanggungjawaban pemimpin/ pengurus korporasi juga diperlukan karena adanya kemungkinan bahwa sanksi senda yang dijatuhkan kepada korporasi tidak akan mempengaruhi kehidupan pemimpin/pengurus korporasi. $^{49}$ Dengan demikian, pertanggungjawaban pribadi pemimpin/pengurus korporasi dimaksudkan untuk menghindarkan adanya perilaku free rider atau moral hazard dari pemimpim/pengurus korporasi apabila yang dapat diminta pertanggungjawaban atas tindak pidana hanyalah korporasi. Karenanya, pandangan perspektif ekonomi tentang pertanggungjawaban pemimpin/pengurus korporasi sebagaimana dikemukakan oleh Bernau, menjadi perlu untuk dikemukakan di sini. Menurut perspektif ini, pertanggungjawaban pemimpin/pengurus korporasi diperlukan untuk menjamin bahwa mereka yang mengambil keputusan di dalam korporasi akan bertangjawab atas keputusan yang diambilnya. Dan pengambil keputusan di dalam korporasi bukanlah korporasi itu sendiri, tetapi para pengurus. ${ }^{50}$

Apabila pertanggungjawaban pemimpin/pengurus korporasi dianggap penting, pertanyaannya kemudian adalah bagaimana membuat seorang pengurus/pemimpin korporasi bertanggung jawab? Jawaban atas pertanyaan ini terdiri dari tiga pendekatan. Pertama, pendekatan

\footnotetext{
${ }^{47}$ Guy Stessens, Op. Cit., hal. 517-518.

${ }^{48}$ Helen Anderson, Directors' Liability for Corporate Faults and Defaults-An International Comparison, "Pacific Rim Law \& Policy Journal", Vol. 18, January, 2009, hal. 58-10.

${ }^{49}$ James Gobert (2011), Op. Cit., hal. 143.

50 Patrick Bernau, Decision and Punishment: Or-Hold Bankers Responsible!: Corporate Criminal Liability fromcan Economic Perspective, dalam: Dominik Brodowski, et al. (eds.), "Regulating Corporate Criminal Liability”, (Dordrecht: Springer, 2014), hal. 48.
} 
pertanggungjawaban pengganti secara pribadi (individual vicarious liability). Kedua, pengurus/pemimpin korporasi bertanggungjawab berdasarkan teori delegasi. Dan Ketiga, karena partisipasi langsung, bantuan, dukungan, atau kegagalan pemimpin/pengurus korporasi dalam mencegah tindak pidana.

\section{a. Pertanggungjawaban Pengganti secara Pribadi (Individual Vicarious Liability)}

Berdasarkan pertanggungjawaban ini, seseorang (dalam hal ini pemimpin/pengurus) bertanggungjawab atas perbuatan pidana orang lain (dalam hal ini pekerja). Menurut Allen, meskipun pertanggungjawaban pengganti secara individu meskipun merupakan praktek yang lazim dilakukan dalam konteks perdata, tetapi cukup jarang digunakan dalam perkara pidana. ${ }^{51}$ Pada dasarnya pertanggungjawaban pidana sifatnya personal, dan karenanya seseorang tidak bisa dimintakan pertanggungjawabannya atas perbuatan orang lain. Hal ini dapat dilihat, misalnya, dari pendapat pengadilan di dalam kasus Huggins. Di dalam kasus ini, Huggins adalah seorang kepala sipir yang didakwa bertanggungjawab atas kematian narapidana karena kesalahan anak buahnya yang menempatkan narapidana tersebut ke dalam sel yang tidak layak. Sebagai dasar penolakan pertanggungjawaban pidana untuk Huggins, pengadilan menyatakan bahwa pada dasarnya atasan dan anak buah bertanggungjawab atas perbuatan masing-masing. Karena dalam kasus ini kesalahan pelaku (anak buah) terjadi tanpa sepengetahuan Huggins, maka ia Huggins dinyatakan tidak bersalah. ${ }^{52}$ Dengan demikian, vicarious liability merupakan bentuk pengecualian dari pertanggungjawaban pidana pada umumnya.

Dalam literatur hukum pidana di Inggris, sebagai pengelualian terhadap prinsip dasar pertanggungjawaban pidana, vicarious liability dapat dilakukan melalui:

1) Tindak pidana menurut putusan pengadilan (common law offences)

Dalam hal ini, vicarious liability bisa muncul dalam kaitannya perbuatan pidana karena adanya gangguan publik (public nuisance). Hal ini bisa diketahui dari kasus Stephens (1866),

${ }^{51}$ Michael J. Allen, "Textbook on Criminal Law", $7^{\text {th }}$ ed. (Oxford: Oxford University Press, 2003), hal. 235.

${ }^{52}$ Ibid.

Pandangan umum pada hukum pidana ini dapat pula dilihat, misalnya, dalam hukum pidana Afrika Selatan sebagaimana diutarakan oleh Snyman bahwa: "In a civilised legal system nobody ought to be held liable for a crime committed not by himself but by another, provided he was not a party to the crime. Only those who acted with culpability ought to be punished - [garisbawah dari penulis]" Lihat: CR Snyman, "Criminal Law", $5^{\text {th }}$ ed. (Durban: LexisNexis, 2008), hal. 371. Pendapat yang sama juga dapat dilihat dalam hukum pidana di Inggris, sebagaimana diutarakan oleh Jefferson, dalam: Michael Jefferson, "Criminal Law", $9^{\text {th }}$ ed. (Essex: Pearson Education Ltd., 2009), hal. 210. 
yang bertanggung jawab atas perbuatan anak buahnya yang membuang sampah ke sungai sehingga mengganggu pelayaran sungai. Stephens bertanggungjawab meskipun ia tidak mengizinkan atau tidak mengetahui bahwa anak buahnya telah melakukan perbuatan yang disangkakan. ${ }^{53}$ Menurut Jefferson, dalam kasus ini pertanggungjawaban pidana atasan (Stephens) didasarkan pada konsep vicarious liability yang berlaku pada pertanggungjawaban perdata; seandainya pertanggungjawaban ini murni didasarkan pada pertanggungjawaban pidana, maka konsep vicarious liability ini tidak dapat diterapkan. ${ }^{54}$

2) ketentuan peraturan perundang-undangan secara eksplisit Peraturan perundang-undangan dapat secara tegas menyatakan bahwa seorang majikan bertanggungjawab atas tindak pidana yang dilakukan oleh pegawainya. Hal ini misalnya dapat dilihat pada Section 9(1) dari Licensing Act 1964 di Inggris yang menyatakan: "[s]ubject to the provisions of this Act, no person shall, except during the permitted hours-(a). himself or by his servant or agent sell or supply to any person in licensed permises...any intoxicating liquor.... ${ }^{55}$ Dalam konteks ini, UU menyatakan bahwa pemilik toko akan bertanggung jawab atas pelanggaran pasal di atas. Contoh lain adalah Section 31 dari Transport Act 1982 di Inggris yang membebankan sanksi pidana denda kepada pemilik kendaraan atas tindak pidana lalu lintas tertentu. Ia bisa lepas dari pertanggungjawaban apabila bisa menunjukkan, misalnya, bahwa pada saat tindak pidana terjadi ia bukanlah pemilik kendaraan atau bahwa kendaraan telah digunakan orang lain tanpa seizinnya. ${ }^{56}$

3) Doktrin "konstruksi secara luas" (extensive construction)

Kadang kala, pengadilan di Inggris menggunakan perluasan penafsiran kepada beberapa kata, seperti "sell" (menjual), "use" (menggunakan), atau "drive" (mengendarai), sedemikian rupa sehingga dikonstruksikan bahwa seseorang akan bertanggungjawab atas perbuatan pidana bawahannya, seolaholah orang tersebutlah yang secara fisik melakukan perbuatan tersebut. Hal inilah yang disebut dengan konstruksi secara luas, extensive construction. Misalnya, seorang majikan bertanggungjawab atas penggunaan kendaraan yang remnya blong oleh bawahannya; pemilik toko bertanggungjawab atas penjualan barang yang memiliki berat yang kurang dari bobot yang tercantum, meskipin kekurangan bobot ini terjadi karena

\footnotetext{
${ }^{53}$ Michael J. Allen, Op. Cit., hal. 234.

${ }^{54}$ Michael Jefferson, Op. Cit., hal. 211.

${ }^{55}$ Dikutip dari: Michael J. Allen, Loc. Cit.

${ }^{56}$ Michael Jefferson, Loc. Cit.
} 
kesalahan bawahan; seorang atasan bertanggungjawab atas penjualan minuman keras secara ilegal oleh pekerjanya meskipun pekerja ini melakukan penjualan ilegal dengan melanggar instruksi atasan. ${ }^{57}$ Menurut Jefferson, doktrin ini mensyaratkan dua hal. Pada satu sisi disyaratkan adanya kewajiban absolut (absolut duty) yang oleh hukum dibebankan kepada atasan. Pada sisi lain disyaratkan adanya perumusan tindak pidana secara strict liability (tidak memerlukan mens rea), sehingga tindakan (actus reus) dari pelaku dapat dilekatkan kepada atasan. ${ }^{58}$ Dengan demikian, doktrin extensive construction terbatas hanya pada delik yang dirumuskan secara strict liability. ${ }^{59}$ Jika tindak pidana mensyaratkan mens rea, maka pertanggungjawaban vicarious liability harus didasarkan pada prinsip delegasi seperti dijelaskan di bawah ini.

4) teori prinsip delegasi (delegation principle) $)^{60}$

Menurut pandangan Pinto dan Evans, pertanggungjawaban berdasarkan teori delegasi muncul "when a statute imposes a duty on a particular category of person [i.e. license holder] and makes breach of the duty an offence". ${ }^{61}$ Artinya, apabila peraturan perundang-undangan menetapkan kewajiban tertentu kepada orang tertentu di dalam korporasi, yaitu pemegang izin, dan peraturan tersebut kemudain menetapkan bahwa tidak dilakukannya kewajiban tersebut adalah sebuah tindak pidana, maka pemegang izin ini akan bertanggung jawab atas pelanggaran yang terjadi, terlepas dari apakah ia telah mendelegasikan pelaksanaan kewajibannya tersebut kepada orang lain atau tidak.

Sementara itu, Law Commissions of England and Wales, menjelaskan bahwa apabila seorang pemegang izin (an officeholder atau a licence-holder) memiliki kewajiban tertentu, dan

${ }^{57}$ Richard Card, “Criminal Law”, 21 $1^{\text {st }}$ ed. (Oxford: Oxford University Press, 2012), hal. 770.

${ }^{58}$ Michael Jefferson, Loc. Cit. Dalam penjelasan Elliot dan Quinn tidak begitu terlihat adanya perbedaan antara vicarious liability berdasarkan perluasan penafsiran (extensive construction) dengan vicarious liability berdasarkan perumusan pasal perundang-undangan secara ekplisit, karena keduanya sepertinya mensyaratkan adanya perumusan pasal tanpa mens rea. Perbedaannya terletak pada apakah vicarious liability dirumuskan secara eksplisit, atau kah merupakan penafsiran yang secara implisit tercermin di dalam rumusan pasal. Lihat: Catherine Elliott dan Frances Quinn, Criminal Law, $3^{\text {rd }}$ ed. (Essex: Pearson Education, Ltd., 2000), hal. 231.

59 The Law Commission, Criminal Law: Involuntary Manslaughter, Consultation Paper No 135, tersedia pada: <http://www.lawcom.gov.uk/wp-content/uploads/2015/06/No.135-Criminal-LawInvoluntary-Manslaughter-A-Consultation-Paper.pdf>, diakses pada bulan Mei 2016, hal. 92.

${ }^{60}$ Perlu diketahui bahwa beberapa pengarang mungkin akan menggolongkan prinsip delegasi sebagai pertanggungjawaban korporasi pada umumnya, dan bukan bagian dari vicarious liability untuk individu (yaitu pemimpin/pengurus korporasi). Lihat misalnya: Sutan Remy Sjahdeini, Op. Cit., hal. 97100.

${ }^{61}$ Amanda Pinto dan Martin Evans, Amanda Pinto dan Martin Evans, "Corporate Criminal Liability", (London: Sweet and Maxwell, 2003), hal. 67. 
ia mendelegasikan pelaksanaan kewajiban tersebut kepada pihak lain, yang kemudian gagal memenuhi kewajiban tersebut, maka pemegang izin tersebut bertanggungjawab atas dasar teori delegasi. Dengan demikian, tidak ada pengatribusian perbuatan seseorang kepada korporasi. Karena itulah maka menurut Law Commission, teori delegasi sebenarnya bukanlah termasuk ke dalam salah satu teori pertanggungjawaban korporasi. ${ }^{62}$

Teori delegasi dapat ditemukan di dalam contoh klasik di Inggris, yaitu dalam Allen v. Whitehead (1930). Kasus ini didasarkan pada adanya pelanggaran terhadap Metropolitan Police Act Tahun 1839 yang mewajibkan pemilik café untuk menjamin bahwa tempat usaha tersebut tidak akan dijadikan tempat berkumpulnya prostitusi. Dalam kasus ini, seorang pemilik café mendelegasikan pengelolaan café kepada seorang manajer, yang ternyata kemudian tanpa sepengetahuan pemilik café mengizinkan prostitusi berkumpul di café tersebut. Dalam hal ini, pemiliki café dianggap bertanggungjawab atas pelanggaran larangan dari Metropolitan Police Act. Pemilik café ini tidak bisa beralasan bahwa ia tidak mengetahui apa yang dilakukan oleh manajernya. ${ }^{63}$

Menurut penulis, sama seperti pada doktrin extensive construction, pertanggungjawaban menurut prinsip delegasi terjadi karena peraturan perundang-undangan telah sedemikian rupa menetapkan bahwa hanya ada satu pihak yang akan bertanggungjawab atas terjadinya pelanggaran terhadap kewajiban, yaitu mereka yang oleh peraturan telah dibebani kewajiban tersebut. Dalam hal ini, karena pemilik café telah dibebankan kewajiban untuk menjamin tidak digunakannya tempat usaha sebagai tempat berkumpulnya prostitusi, maka pelanggaran atas kewajiban tersebut akan membuat pemilik café bertanggung jawab. Adapun perbedaan dengan doktrin extensive construction, pada prinsip delegasi atasan bisa bertanggungjawab untuk perbuatan yang mensyaratkan adanya mens rea. Akibatnya, pada prinsip delegasi, pertanggungjawaban atasan mensyaratkan adanya delegasi secara utuh (full delegation), sehingga atasan yang tidak mengetahui atas fakta-fakta terkait tindak pidana, tidak akan bertanggung jawab. Lebih dari itu, Jefferson juga menyatakan bahwa prinsip delegasi hanya dapat diterapkan kepada subjek hukum orang, dan bukan untuk korporasi. ${ }^{64}$

62 The Law Commission of England and Wales, Criminal Liability in Regulatory Contexts: A Consultation Paper, Consultation Paper No 195, 2010, tersedia pada <http://www.lawcom.gov.uk/wpcontent/uploads/2015/06/cp195_Criminal_Liability_ consultation.pdf $>$, diakses pada Februari 2016, par. 7.53, hal. 145 .

${ }^{63}$ Michael J. Allen, Op. Cit., hal. 237.

${ }^{64}$ Michael Jefferson, Op. Cit., hal. 214-215. 
Lebih jauh lagi, dalam penerapan individual vicarious liability, ada baiknya kita merujuk pada beberapa hal/ukuran sebagaimana diturakan oleh Snyman pada saat membahas vicarious liability di Afrika Selatan. Menurut Snyman, ukuran yang berlaku untuk strict liability, berlaku pula untuk vicarious liability. Ukuran tersebut yaitu: a). Bagaimana bahasa yang digunakan oleh pembuat undangundang, dalam arti apakah vicarious liability secara tegas dirumuskan dalam tindak pidana tertentu, ataukah merupakan implikasi yang akan dihasilkan dari perumusan tindak pidana tersebut. b). apakah lingkup dan tujuan dari perumusan pasal pidana (the scope and purpose of the prohibition). Dalam hal ini, sama seperti untuk strict liability, pertanggungjawaban vicarious liability biasanya ditujukan untuk perbuatan yang menggangung kesejahteraan/ketertiban umum. c). beratnya sanksi (the measure of punishment). Semakin ringan sanksi yang diancamkan, semakin mungkin vicarious liability berlaku. d). apakah tujuan dari pembuat undang-undang tidak akan tercapat tanpa adanya penerapan vicarious liability. e). apakah atasan memperolah keuntungan dari perbuatan bawahan. Vicarious liability berlaku jika atasan memperoleh keuntungan dari perbuatan pidana bawahan. f). apakah undangundang secara tegas membatasi siapa yang akan terkena pertanggungjawaban. Jika UU menentukan bahwa yang akan bertanggjawab hanyalah orang tertentu, misalnya pemegang izin, maka vicarious liability berlaku. ${ }^{65}$

\section{b. Karena Partisipasi, Bantuan, Persetujuan, atau Kegagalan Melakukan Pengawasan}

Di AS, pertanggungjawaban pemimpin/pengurus korporasi dapat didasarkan pada tiga alasan sebagaimana diutarakan oleh Webb, dkk. berikut ini: Pertama, adanya partisipasi langsung di dalam tindak pidana. Dalam hal ini, pertanggungjawaban pribadi dimaksudkan agar seorang pelaku tidak bisa menghindar dari pertanggungjawaban dengan cara berlindung di balik pertanggungjawaban korporasi. ${ }^{66}$

Hal ini sejalan dengan pandangan Fisse dan Braithwaise, sebagaimana diutarakan pada Bagian 2, yang menyatakan bahwa dalam rangka menjamin adanya akuntabilitas dari korporasi, maka pertanggungjawaban harus dikenakan kepada siapa pun yang di dalam korporasi yang bisa dimintakan pertanggungjawaban, baik itu pelaku, pengurus/pemimpin, atau korporasinya itu sendiri.

\footnotetext{
${ }^{65}$ C.R. Snyman, Op. Cit., hal. 251.

${ }^{66}$ Dan K. Webb, Steven F. Molo dan James F. Hurst, Op. Cit., hal. 627.
} 
Kedua, adanya bantuan atau dorongan untuk melakukan tindak pidana. Dalam hal ini, pertanggungjawaban oleh pengurus muncul jika pengurus dianggap memfasilitasi, membantu, mendorong, memberikan arahan, atau menyetujui dilakukannya tindak pidana, baik melalui tindakan aktif tertentu maupun melalui tidak dilakukannya langkah tertentu. Dilakukan atau tidak dilakukannya upaya ini yang dianggap mengakibatkan terjadinya tindak pidana. ${ }^{67}$

Ketiga, adanya kegagalan melalukan pengawasan. Kriteria ini didasarkan pada doktrin "the Responsible Corporate Officer" (RCO), yang menyatakan bahwa pengurus/pemimpin korporasi dapat dipidana untuk tindak pidana dari bawahannya, meskipun pengurus/pemimpin korporasi tidak mengetahui secara spesifik tindak pidana apa yang telah dilakukan oleh bawahannya. Dalam hal ini, untuk memidana pemimpin/pengurus korporasi maka jaksa diminta untuk membuktikan bahwa pengurus/pemimpin korporasi memiliki kekuasaan untuk membenahi atau mencegah terjadinya pelanggaran pidana. $^{68}$ Terkait kriteria ini, Webb, dkk mengetengahkan putusan kasus United States v. Park. Dalam kasus ini, pemimpin korporasi bersama-sama dengan korporasi didakwa karena melanggar Food, Drug and Cosmetic Act (FDCA). Pertanyaan penting di sini adalah apakah terdakwa (Park) dalam tindak pidananya memegang posisi dan tanggungjawab. Jika iya, maka terdakwa bertanggungjawab karena posisinya sebagai pihak yang memikul tanggung jawab. Dalam hal ini, kesalahan dapat diatribusikan kepada pemimpin/pengurus korporasi meskipun ia tidaklah secara sadar melakukan tindak pidana, atau bahwa ia tidak secara langsung berpartisipasi dalam tindak pidana. ${ }^{69}$ Dengan merujuk pada pertimbangan dalam United States $v$. Dotterweich dan United States v. Park, Bragg, dkk menyimpulkan bahwa di dalam Doktrin RCO, seorang pengurus/pemimpin korporasi akan bertanggungjawab untuk terjadinya tindak pidana di dalam korporasi apabila pada satu sisi terbukti bahwa pengurus/pemimpin tersebut, karena posisinya di dalam korporasi, memiliki tanggung jawab dan kekuasaan untuk mencegah terjadinya tindak pidana, untuk mengoreksi tindak pidana yang terjadi; sedang pada sisi lain terbukti pula bahwa ia gagal untuk melakukan tanggung jawab tersebut. ${ }^{70}$

\footnotetext{
${ }^{67}$ Ibid., hal. 627-628.

${ }^{68}$ Ibid., hal. 628.

${ }^{69}$ Ibid., hal. 628-629.

${ }^{70}$ Jennifer Bragg, John Bentivoglio, dan Andrew Collins, Onus of Responsibility: The Changing Responsible Corporate Officer Doctrine, "Food and Drug Law Journal", Vol. 65, 2010, hal. 525.
}

Dengan berdasarkan pada pandangan Agaard, penulis berpandangan bahwa Doktrin RCO berbeda dengan vicarious liability karena beberapa alasan. Pertama, di dalam RCO, terdakwa memenuhi semua unsur tindak pidana, tanpa perlu merujuknya dengan perbuatan orang lain. Artinya, di dalam RCO kesalahan dan tanggungjawab terdakwa (pemimpin) tidaklah tergantung dari kesalahan dan tanggung jawab pihak lain (bawahan). Kedua, RCO sepenuhnya fokus pada terdakwa. Satu-satunya rujukan pada 
Untuk meminta pemimpin/pengurus bertanggungjawab atas perbuatan orang lain, penuntut umum haruslah mampu menunjukkan bahwa pemimpin/pengurus memiliki kewenangan untuk memastikan adanya penaatan (compliance) di dalam organisasi yang dipimpinnya, sehingga ia memiliki kewajiban untuk melakukan pengawasan dan mencegah terjadi tindak pidana. ${ }^{71}$ Kegalalan melakukan pengawasan dan pencegahan ini menimbulkan pertanggungjawaban pidana dari pemimpin/pengurus.

Doktrin RCO telah pula diterapkan di dalam kasus lingkungan di AS. Dalam United States v. Iverson, terdakwa yaitu seorang pemimpin perusahaan kimia didakwa melanggar Clean Water Act yang melarang pembuangan limbah pada kawasan air yang dilindungi. Dalam kasus ini, pekerja terdakwa membersihkan drum yang mengandung limbah B3, sehingga limbah tersebut masuk ke dalam sistem pembuangan umum. Dalam kasus ini terbukti bahwa terdakwa mengetahui terjadinya pembuangan limbah, meskipun ia secara pribadi tidak melakukan pembuangan limbah tersebut. Menurut pengadilan, terdakwa akan bertanggungjawab apabila: a). terdakwa mengetahui bahwa ada pembuangan yang dilakukan oleh anak buahnya; b). terdakwa memiliki kekuasaan/kewenangan untuk mencegah terjadinya tindak pidana (yaitu pembuangan limbah); dan c). terdakwa gagal mencegah terjadinya tindak pidana tersebut. ${ }^{72}$ Lebih jauh lagi, pengadilan dalam United States $v$. Iverson menyatakan bahwa meskipun Doktrin RCO membebaskan penuntut umum dari beban untuk membuktikan bahwa terdakwa adalah pihak yang membuang atau menyebabkan terjadinya tindak pidana (pembuangan limbah), Doktrin ini tetap meminta penuntut umum untuk mampu membuktikan bahwa pembuangan limbah adalah

perbuatan orang lain ialah bahwa pertanggungjawaban terdakwa dalam RCO dipicu oleh adanya pelanggaran hukum oleh orang lain. Dalam arti ini, tanggungjawab terdakwa dalam doktrin RCO terjadi karena terdakwa memiliki tanggung jawab untuk mencegah dan mengoreksi pelanggaran hukum; dan ia gagal melakukan tanggung jawab itu. Bagaimana pelanggaran tersebut terjadi, siapa saja yang terlibat di dalamnya, atau apakah pelanggaran tersebut merupakan tindak pidana atau bukan, tidaklah relevan dalam penentuan pertanggungjawaban pemimpin/pengurus. Dengan demikian, menurut doktrin RCO ini, pada saat terjadinya pelanggaran, pemimpin/pengurus sendiri dianggap melakukan tindak pidana berupa kegagalan melakukan tanggung jawab pencegahan dan melakukan tindakan koreksi atas pelanggaran hukum yang terjadi. Ketiga, tanggung jawab pemimpin/pengurus dalam doktrin RCO adalah tanggung jawab pribadi, yang muncul bukan karena ia berpartisipasi dalam pelanggaran hukum, tetapi karena kegagalannya mencegah terjadinya pelanggaran. Lihat: Todd S. Aagaard, A Fresh Look At The Responsible Relation Doctrine, "Journal of Criminal Law \& Criminology", Vol. 96, 2006, hal. 12891290.

Untuk komentar terhadap doktrin RCO atau Doktrin Park, lihat misalnya: Peter J. Henning, A New Crime For Corporate Misconduct?, “Mississippi Law Journal”, Vol. 84, 2014, hal. 43-88.

${ }^{71}$ Marshall B. Clinard and Peter C. Yeager, "Corporate Crime”, (New York: The Free Press, 1980), hal. 281.

${ }^{72}$ Amiad Kushner, Applying The Responsible Corporate Officer Doctrine Outside The Public Welfare Context, “Journal of Criminal Law \& Criminology”, Vol. 93, 2003, hal. 705-706. 
tindak pidana dan bahwa terdakwa mengetahui adanya pembuangan (tindak pidana) tersebut. ${ }^{73}$

Di Inggris, pertanggungjawaban pemimpin/pengurus korporasi diterapkan jika tindak pidana dilakukan atas dasar persetujuan (consent), persengkongkolan (connivance), atau atas dasar adanya kelalaian (neglect) pada pihak pemimpin/pengurus. Dalam hal ini, Trades Descriptin Act Tahun 1968, sebagaimana dikutip oleh Pinto dan Evans, yang pada Section 20 (1) menyatakan bahwa:

Where an offence under this Act which has been committed by a body corporate is proved to have been committed with the consent or connivance of, or to be attributable to any neglect on the part of, any director, manager, secretary or other similar officer ot the body corporate or any person who was purpoting to act in any such capacity, he as well as the body corporate shall be guilty of that offence. ${ }^{74}$

Menurut Pinto dan Evans, perbedaan persetujuan (consent) dengan persekongkolan (connivance) adalah bahwa dalam consent tidak selalu diperlukan adanya pengetahuan aktual (actual knowledge) dari pemimpin/pengurus, sedangkan di dalam connivance pengetahuan tersebut diperlukan. Lebih jauh lagi, Pinto dan Evans juga menyatakan bahwa connivance mengindikasikan adanya tingkat keterlibatan pemimpin/pengurus korporasi yang lebih dalam dibandingkan dengan consent. Sementara itu, oleh kedua pengarang ini neglect diartikan sebagai kegagalan untuk melakukan sesuatu kewajiban, dalam arti bahwa pemimpin/pengurus korporasi tidak melakukan kewajiban yang secara layak diharapkan darinya. ${ }^{75}$

Khusus mengenai neglect ini, ada baiknya jika kita merujuk pula kriteria yang dikembangkan dazlam kasus Wotherspoon $v H M$ Advocate, sebagaimana dirangkum oleh Foster, di antaranya: Pertama, istilah lalai (neglect) mengandaikan adanya kewajiban tertentu yang gagal dilakukan oleh seseorang. Kedua, pembuktian adanya kelalaian ini tidak bisa dilakukan tanpa identifikasi adanya kegagalan dari pemimpin/pengurus korporasi untuk mengambil langkah tertentu yang diwajibkan kepadanya. Ketiga, karena itu pengetahuan atau kesadaran pemimpin/pengurus korporasi bahwa

${ }^{73}$ Nancy Mullikin, Holding the "Responsible Corporate Officer" Responsible: Addressing the Need for Expansion of Criminal Liability for Corporate Environmental Violators, "Golden Gate University Environmental Law Journal”, Vol. 3, 2010, hal. 417.

${ }^{74}$ Amanda Pinto dan Martin Evans, Op. Cit., hal. 81-82.

${ }^{75}$ Ibid., hal. 82. 
tindakan tertentu seharusnya perlu diambil menjadi sangat relevan untuk dibuktikan. ${ }^{76}$

Sementara itu, pertanggungjawaban pemimpin/pengurus korporasi terdapat pula dalam beberapa undang-undang di Australia. Di negara bagian New South Wales (NSW), misalnya, Occupational Health and Safety Act Tahun 2000 (selanjutnya disebut OHS Act 2000) mengandung ketentuan yang memuat pertanggungjawaban bagi pemimpin/pengurus korporasi. Dalam hal ini, Section 26 dari OHS Act 2000 menyatakan bahwa apabila korporasi dianggap telah melalukan tindak pidana, maka pemimpin/pengurus korporasi dianggap telah pula melakukan tindak pidana, kecuali pemimpin/ pengurus korporasi dapat membuktikan mereka tidak dalam posisi untuk mempengaruhi perilaku korporasi untuk melakukan tindak pidana. Apabila pemiminpin/pengurus berada dalam posisi untuk mempengaruhi perilaku korporasi, maka pemimpin/pengurus harus membuktikan bahwa mereka telah melakukan segala cara yang layak (all due dilligence) untuk mencegah terjadinya tindak pidana. ${ }^{77}$

Oleh Foster, ketentuan tersebut dijelaskan sebagai berikut: Pertama, pertanggungjawaban pribadi pemimpin/pengurus korporasi hanya ada apabila sebelumnya korporasi telah terbukti melakukan tindak pidana. Kedua, yang dapat bertanggungjawab tidaklah terbatas hanya pada dewan direksi, tetapi juga para pihak yang terlibat dalam manajemen korporasi (concerned in management). Ketiga, terdapat praduga bersalah terhadap pemimpin/pengurus korporasi. Dalam hal ini, apabila korporasi dianggap telah terbukti melakukan tindak pidana, maka pemimpin/pengurus korporasi karena kedudukannya dianggap telah pula terbukti melakukan tindak pidana, kecuali mereka bisa membuktikan bahwa mereka tidak mampu mempengaruhi perilaku korporasi atau jika mereka telah melakukan segala upaya untuk mencegah pelanggaran. Keempat, beban pembuktian ada pada pemimpin/pengurus korporasi. ${ }^{78}$

${ }^{76}$ Neil Foster, Individual Liability of Company Officers, dalam James Gobert dan Ana-Maria Pascal (eds.), "European Developments in Corporate Criminal Liability”, (London: Routledge, 2011), hal. 121.

${ }^{77}$ Section 26 dari OHS Act 2000, sebagaimana dikutip oleh Foster, menyatakan:

"Offences by corporations - liability of directors and managers

(1). If a corporation contravenes, whether by act or omission, any provision of this Act or the regulations, each director of the corporation, and each person concerned in the management of the corporation, is taken to have contravened the same provision unless the director or person satisfies the court that:

a). he or she was not in a position to influence the conduct of the corporation in relation to its contravention of the provision, or

$b)$. he or she, being in such a position, used all due diligence to prevent the contravention by the corporation.

Lihat: Ibid., hal. 124.

${ }^{78}$ Ibid. 
Rangkuman dari pertanggungjawaban pemimpin/pengurus korporasi dapat dilihat dalam Tabel 2 Lampiran dari tulisan ini.

\section{Pertanggungjawaban Korporasi Menurut Peraturan Perundangan- undangan Bidana Lingkungan Hidup dan Penerapannya di Pengadilan}

Dalam bagian ini akan dipaparkan mengenai perumusan pertanggungjawaban korporasi dalam berbagai peraturan perundang-undangan, serta bagaimana pertanggungjawaban tersebut diterapkan di dalam kasus pencemaran lingkungan.

\section{Pertanggungjawaban Korporasi dan Pemimpin/Pengurus Korporasi menurut Peraturan Perundang-undangan}

\section{a. UU Lingkungan Hidup}

Ketentuan mengenai pertanggungjawaban korporasi di dalam UU No. 32 Tahun 2009 dapat dilihat dalam ketentuan Pasal 116 s.d. 120. Tulisan ini hanya akan membahas beberapa pasal saja dari ketentuan tersebut.

Pasal 116 UU No. 32 Tahun 2009 menyatakan:

(1) Apabila tindak pidana lingkungan hidup dilakukan oleh, untuk, atau atas nama badan usaha, tuntutan pidana dan sanksi pidana dijatuhkan kepada:

a. badan usaha; dan/atau

b. orang yang memberi perintah untuk melakukan tindak pidana tersebut atau orang yang bertindak sebagai pemimpin kegiatan dalam tindak pidana tersebut.

(2) Apabila tindak pidana lingkungan hidup sebagaimana dimaksud pada ayat (1) dilakukan oleh orang, yang berdasarkan hubungan kerja atau berdasarkan hubungan lain yang bertindak dalam lingkup kerja badan usaha, sanksi pidana dijatuhkan terhadap pemberi perintah atau pemimpin dalam tindak pidana tersebut tanpa memperhatikan tindak pidana tersebut dilakukan secara sendiri atau bersama-sama.

Sementara itu, Pasal 118 UU No. 32 Tahun 2009 menyatakan bahwa "[t]erhadap tindak pidana sebagaimana dimaksud dalam Pasal 116 ayat (1) huruf a, sanksi pidana dijatuhkan kepada badan usaha yang diwakili oleh pengurus yang berwenang mewakili di dalam dan di luar pengadilan sesuai dengan peraturan perundang-undangan selaku pelaku fungsional." Sepintas, Pasal ini sudah tepat, yaitu bahwa dalam hal tuntutan dan sanksi pidana dijatuhkan kepada korporasi, maka korporasi itu diwakili oleh pengurus. 
Kebingungan justru terjadi apabila kita membaca Penjelasan dari Pasal 118 UU No. 32 Tahun 2009, yang berbunyi:

Yang dimaksud dengan pelaku fungsional dalam Pasal ini adalah badan usaha dan badan hukum. Tuntutan pidana dikenakan terhadap pemimpin badan usaha dan badan hukum karena tindak pidana badan usaha dan badan hukum adalah tindak pidana fungsional sehingga pidana dikenakan dan sanksi dijatuhkan kepada mereka yang memiliki kewenangan terhadap pelaku fisik dan menerima tindakan pelaku fisik tersebut.

Yang dimaksud dengan menerima tindakan dalam Pasal ini termasuk menyetujui, membiarkan, atau tidak cukup melakukan pengawasan terhadap tindakan pelaku fisik, dan/atau memiliki kebijakan yang memungkinkan terjadinya tindak pidana tersebut.

Dengan memperhatikan Penjelasan ini, terutama frasa "tuntutan pidana dikenakan terhadap pemimpin badan usaha dan badan hukum" maka kita memperoleh kesan bahwa apabila apabila tuntutan dan sanksi pidana dijatuhkan kepada korporasi, maka sanksi tersebut sebenarnya ditujukan kepada pemimpin/pengurus korporasi. Dalam hal ini, mereka tidak bertindak sebagai wakil dari korporasi di pengadilan, tetapi memang sebagai pihak yang menjalankan sanksi pidana. Dengan interpretasi ini, UU No. 32 Tahun 2009 menjadi tidak lagi menganut pertanggungjawaban korporasi, baik dalam arti korporasi bertanggungjawab atas perbuatan seseorang atau atas perbuatannya sendiri; tetapi menganut pertanggungjawaban pengganti individual (individual vicarious liability), di mana pemimpin korporasi bertanggungjawab atas perbuatan orang lain atau perbuatan korporasi.

Pemahaman yang janggal tentang pertanggungjawaban korporasi dapat dilihat pada rumusan Pasal 119 UU No. 32 Tahun 2009. Pasal ini menyatakan bahwa "[s]elain pidana sebagaimana dimaksud dalam Undang-Undang ini, terhadap badan usaha dapat dikenakan pidana tambahan atau tindakan tata tertib berupa:..." Pasal ini berarti bahwa untuk korporasi selain dari pidana pokok yang dikenal dalam UU No. 32 Tahun 2009, dapat pula dikenakan pidana tambahan atau tata tertib. Dengan rumusan kalimat seperti itu, maka untuk korporasi tidak bisa dikenakan hanya pidana tambahan atau tata tertib, tanpa disertai dengan pidana pokoknya. Pertanyaannya kemudian, apakah pidana pokok yang ada dalam UU No. 32 Tahun 2009. Apabila kita menelusuri ketentuan pidana dalam UU No. 32 Tahun 2009, yaitu Pasal 98 s.d. 115, maka segera akan kita ketahui bahwa pidana pokok yang dikenal di dalam UU No. 32 Tahun 2009 adalah penjara dan denda. Tidak boleh hanya penjara, dan tidak 
boleh pula hanya denda. Dari cara perumusunan ini, maka muncul kesimpulan yang aneh: korporasi bisa dikenakan pidana penjara!

Berdasarkan penjelasan di atas, penulis beranggapan bahwa Pasal 116 dan 118 UU No. 32 Tahun 2009 beserta penjelasannya dapat diartikan sebagai berikut: Pertama, UU No. 32 Tahun 2009 membuka kemungkinan diterapkannya corporate vicarious liability, yaitu dalam hal tindak pidana untuk atau nama korporasi menimbulkan pertanggungjawaban korporasi (Pasal 116 ayat (1) huruf a). Kedua, UU membuka kemungkinan diterapkannya individual vicarious liability, yaitu jika pasal 116 ayat (1) huruf a diterjemahkan berdasarkan Penjelasan Pasal 118. Menurut penulis penafsiran pertama (tentang corporate vicarious liability) dan penafsiran kedua (tentang individual vicarious liability) tidaklah mungkin diterapkan bersama-sama, karena kedua penafsiran yang bertolak belakang ini terkait dengan penafsiran atas satu Pasal yang sama, yaitu Pasal 116 ayat (1) huruf a. Ketiga, UU juga membuka kemungkinan pertanggungjawaban pribaddi dari pelaku (yaitu pemberi perintah dalam tindak pidana dan pemimpin tindak pidana), seperti dinyatakan dalam Pasal 116 ayat (1) huruf b, dan Pasal 116 ayat (2). Keempat, Pasal 116 ayat (1) huruf b tidaklah menunjukkan bahwa UU menganut individual vicarious liability, karena "pemberi perintah" dan "pemimpin" di sini tidak bersifat umum (dalam arti terkait dengan struktur korporasi), melainkan bersifat khusus dalam arti merupakan "pemberi perintah dan pemimpin dalam tindak pidana”.

\section{b. SK Ketua MA dan Peraturan Jaksa Agung terkait Pertanggungjawaban Korporasi}

Penafsiran penegak hukum terkait tindak pidana dan pertanggungjawaban korporasi dapat pula dilihat dalam Surat Keputusan Ketua Mahkamah Agung dan Peraturan Jaksa Agung. Di dalam Lampiran dari Keputusan Ketua MA No. 036/KMA/SK/II/2013 tentang Pedoman Penangan Perkara Lingkungan Hidup, dijelaskan bahwa apabila tindak pidana lingkungan hidup dilakukan oleh, untuk, atau atas nama korporasi, maka tuntutan dan sanksi pidana dijatuhkan kepada: a), korporasinya, b). Orang yang memberikan perintah, yaitu orang dengan jabatan yang sesuai atau Pengurus/direksi sesuai Anggaran Dasar; c). Pemimpin badan usaha.

Menurut penulis, SK Ketua MA ini tidak menjawab berbagai persoalan yang dikemukakan terkait pertanggungjawaban korporasi dan pemimpin/pengurus korporasi yang menurut penulis menjadi persoalan dari UU No. 32 Tahun 2009. Misalnya saja, SK Ketua MA tersebut tidak menjelaskan apa perbedaan antra pertanggungjawaban untuk orang yang memberikan perinah, yang diartikan sebagai 
pengurus/direksi; dengan pertanggungjawaban oleh pemimpin badan usaha. Bukankah keduanya relatif sama saja?

Lebih penting lagi, SK Ketuan MA ini menguraikan pula beberapa hal yang dapat dijadikan pembalan oleh terdakwa di dalam kaitannya dengan pertanggungjawaban pidana, antara lain: "a. direksi menerima laporan bahwa pengelolaan lingkungan hidup sudah sesuai dengan peraturan atau izin; b. Direksi tidak menerima laporan dari operator mengenai kegiatan yang terkait dengan tindak pidana; $\mathrm{c}$. direksi membuktikan telah melakukan tindakan-tindakan sesuai dengan SOP tetapi diabaikan oleh bawahannya; d. Operator dapat membuktikan bahwa dia sudah melaporkan kepada atasan dan diteruskan kepada direksi dan tidak ditanggap". ${ }^{79}$

Sementara itu, pada tahun 2014, Jaksa Agung juga menerbitkan Peraturan Jaksa Agung RI No. Per-028/A/JA/10/2014 tentang Pedoman Penanganan Perkara Pidana dengan Subjek Hukum Korporasi (selanjutnya disebut PerJA Tahun 2014). Di dalam Lampiran dari PerJA Tahun 2014 tersebut antara lain dijelaskan beberapa tindakan korporasi yang dapat dimintakan pertanggungjawaban, di antaranya: a). semua perbuatan yang didasarkan pada keputusan pengurus; b). berbuat atau tidak berbuatnya seseorang untuk kepentingan korporasi; c). perbuatan yang menggunakan sumber daya manusia, dana, atau dukungan/fasilitas korporasi; d). perbuatan yang dilakukan oleh pihak ketiga atas permintaan atau perintah dari korporasi atau pengurus korporasi; e). Perbuatan dalam rangka menjalankan kegiatan sehari-hari korporasi; f). perbuatan yang menguntungkan korporasi; g). tindakan yang biasanya diterima (accepted) oleh korporasi; h). Korporasi yang secara nyata menampung hasil tindak pidana. ${ }^{80}$

Selain itu, PerJA 2014 juga menentukan beberapa perbuatan pengurus korporasi yang dapat dimintakan pertanggungajwaban pidana, di antaranya: a). setiap orang yang melakukan, turut serta melakukan, menyuruh, menganjurkan, atau membatu tindak pidana; b). setiap orang yang memiliki kendali dan wewenang untuk mengambil langkah pencegahan tindak pidana, namun tidak mengambil langkah yang seharusnya; dan c). orang yang memiliki pengetahuan akan adanya risiko yang cukup besar dan mengetahui ahwa tindak pidana akan dilakukan oleh korporasi. ${ }^{81}$ Lebih jauh lagi, PerJA 2014 juga memuat Formulir 1 yang berisi format untuk

\footnotetext{
${ }^{79}$ Lihat Lampiran Keputusan Ketua MA No. 036/KMA/SK/II/2013 tentang Pedoman Penangan Perkara Lingkungan Hidup.

${ }^{80}$ Peraturan Jaksa Agung RI No. Per-028/A/JA/10/2014 tentang Pedoman Penanganan Perkara Pidana dengan Subjek Hukum Korporasi, Lampiran hal. 3-4.

${ }^{81}$ Peraturan Jaksa Agung RI No. Per-028/A/JA/10/2014 tentang Pedoman Penanganan Perkara Pidana dengan Subjek Hukum Korporasi, Lampiran hal. 5.
} 
terdakwa berupa korporasi, Formulir 2 yang berisi format untuk terdakwa pengurus korporasi, dan Formulir 3 jika terdakwa korporasi dan pengurus disatukan dalam satu berkas.

Pembedaan yang dilakukan oleh PerJA 2014 patut diapresiasi, karena menunjukkan bahwa PerJA dapat membedakan pertanggungjawaban korporasi dengan pertanggungjawaban pribadi dari pemimpin/pengurus korporasi. Apresiasi lebih perlu pula diberikan kepada PerJA 2014 ini terkait dengan kriteria untuk mentukan perbuatan pengurus korporasi yang dapat memicu pertanggungjawaban pribadi. Menurut penulis, kriteria ini sedikit banyak lebih dekat dengan berbagai teori yang sudah dijelaskan pada Bagian 2.2. Persoalannya, tentu saja, apakah PerJA 2014 dapat diterapkan untuk tindak pidana korporasi di bidang lingkungan hidup mengingat perumusan di dalam UU No. 32 Tahun 2009 yang cukup membingungkan.

\section{c. Pertanggungjawaban Korporasi menurut UU No. 41 Tahun 1999}

Menurut Pasal 78 ayat (14) UU No. 41 Tahun 1999, untuk tindak pidana kehutanan yang "dilakukan oleh dan atau atas nama badan hukum atau badan usaha, tuntutan dan sanksi pidananya dijatuhkan terhadap pengurusnya, baik sendiri-sendiri maupun bersama-sama...". Penjelasan dari Pasal 78 ayat (14) menyatakan bahwa "[y]ang termasuk badan hukum dan atau badan usaha, antara lain perseroan terbatas, perseroan komanditer (comanditer venootschaap), firma, koperasi, dan sejenisnya."

Dengan demikian, dari ketentuan mengenai tindak pidana korporasi menurut UU No. 41 Tahun 1999 dapat disimpulkan hal sebagai berikut: Pertama, dalam mendefinisikan korporasi, UU ini mengikuti model Perancis, yaitu melalui penentuan jenis korporasi macam apa saja yang dapat dimintai pertanggungjawaban. Dalam hal ini, korporasi didefinisikan sebagai "perseroan terbatas, perseroan komanditer (comanditer venootschaap), firma, koperasi, dan sejenisnya". Kedua, UU No. 41 Tahun 1999 tidak menyediakan sanksi pidana bagi korporasi. Dengan demikian, UU ini tidak menganut pertanggungjawaban korporasi baik atas perbuatan orang maupun atas perbuatan sendiri. Ketiga, sebaliknya, UU No. 41 Tahun 1999 justru menganut individual vicarious liability, di mana pengurus korporasi akan bertanggungjawab atas perbuatan dari bawahan, dirinya sendiri, atau bahkan perbuatan korporasi. Hal ini terlihat dari ketentuan yang menyatakan bahwa apabila tindak pidana dilakukan oleh korporasi maka "tuntutan dan sanksi pidananya dijatuhkan terhadap pengurusnya". 


\section{d. Pertanggungjawaban Korporasi Menurut UU No. 18 Tahun 2013}

Rumusan pertanggungjawaban korporasi yang cukup membingungkan dapat ditemukan dalam UU No. 18 Tahun 2013 tentang Pencegahan dan Pemberatasan Perusakan Hutan. Pada Pasal 82 ayat (3), UU No. 18 Tahun 2013 menyatakan:

Korporasi yang:

a). melakukan penebangan pohon dalam kawasan hutan yang tidak sesuai dengan izin pemanfaatan hutan ...;

b). melakukan penebangan pohon dalam kawasan hutan tanpa memiliki izin ...; dan/atau

c). melakukan penebangan pohon dalam kawasan hutan secara tidak sah ...

dipidana dengan pidana penjara paling singkat 5 (lima) tahun dan paling lama 15 (lima belas) tahun serta pidana denda paling sedikit $R p$ 5.000.000.000,00 (lima miliar rupiah) dan paling banyak Rp 15.000.000.000,00 (lima belas miliar rupiah).

Tata cara perumusan sanksi pidana bagi korporasi tersebut kemudian diulang lagi di dalam berbagai ketentuan dari UU No. 18 Tahun 2013. Dengan cara perumusan tersebut, UU sepertinya hendak menyatakan bahwa pada dasarnya semua tindak pidana terkait pembalakan liar yang dapat dilakukan oleh manusia, dianggap dapat pula dilakukan oleh korporasi. ${ }^{82}$ Dari perumusan tersebut, maka dapat disimpulkan bahwa UU No. 18 Tahun 2013 secara tegas telah memungkinkan dijatuhkannya pidana penjara bagi korporasi!

Tentu saja memenjarakan korporasi adalah sebuah kekeliruan fatal. Anehnya, kekeluaran ini sendiri tampaknya disadari oleh pembuat undang-undang, karena dalam Pasal 109 ayat (5), UU No. 18 Tahun 2013 menyatakan bahwa "Pidana pokok yang dapat dijatuhkan terhadap korporasi hanya pidana denda sebagaimana dimaksud dalam Pasal 82 sampai dengan Pasal103." Dengan demikian, Ayat ini mencoba menganulir sanksi pidana bagi korporasi seperti dirumuskan pada Pasal 82 s.d. 103, yang telah memuat sanksi penjara dan denda. Persoalannya, apabila kemudian dianulir pada Pasal 109, maka untuk apa pembuat undang-undang tetap mencantumkan sanksi penjara bagi korporasi di dalam Pasal 82 s.d. 103 ?

Lebih jauh lagi, Pasal 109 ayat (1) UU No. 18 Tahun 2013 menyatakan apabila tindak pidana terkait pembalakan liar "dilakukan

\footnotetext{
82 Lihat perumusan sanksi pidana untuk korporasi dalam: UU No. 18 Tahun 2013 tentang Pencegahan dan Pemberantasan Perusakan Hutan, LN Tahun 2013 No. 130, TLN No. 5432 [selanjutnya disebut UU No. 18 Tahun 2013], Pasal 83 s.d. Pasal 103.
} 
oleh atau atas nama suatu korporasi, tuntutan dan/atau penjatuhan pidana dilakukan terhadap korporasi dan/atau pengurusnya." Selanjutnya, Pasal 109 ayat (2) UU No. 18 Tahun 2013 menyatakan bahwa tindak pidana terkait pembalakan liar dianggap dilakukan oleh korporasi "apabila tindak pidana tersebut dilakukan oleh orang perorangan, baik berdasarkan hubungan kerja maupun hubungan lain, bertindak dalam lingkungan korporasi tersebut baik secara sendiri maupun bersama-sama". Sedangkan Pasal 109 ayat (3) UU No. 18 Tahun 2013 menyatakan bahwa jika tuntutan pidana dilakukan terhadap korporasi, maka korporasi tersebut diwakili oleh pengurus.

Dari rumusan Pasal ini, dapat disimpulkan bahwa UU No. 18 Tahun 2013 memungkinkan sanksi pidana untuk dijatuhkan kepada korporasi maupun pengurus korporasi. Dengan dapat dipidananya pengurus korporasi atas perbuatan seseorang di dalam lingkup kerja korporasi, sebagaimana tercermin dalam Pasal 109 ayat (1) dan (2) UU No. 18 Tahun 2013, maka terlihat bahwa UU ini menganut individual vicarious liability. Dalam hal ini, pengurus korporasi bertanggungjawab atas tindak pidana yang dilakukan oleh siapa pun yang berada di bawah lingkup kerja korporasi. Selain itu, dengan dapat dipidananya korporasi, maka terlihat bahwa UU No. 18 Tahun 2013 membuka diterapkannya berbagai teori pertanggungjawaban korporasi, mulai dari corporate vicarious liability, teori agregasi, teori identifikasi, ataupun teori budaya korporasi.

\section{e. Pertanggungjawaban Korporasi Menurut UU No. 39 Tahun 2014}

Rumusan pertanggungjawaban korporasi dapat pula ditemukan dalam UU No. 39 Tahun 2014 tentang Perkebunan. Menurut Pasal 113 ayat (1) UU No. 39 Tahun 2014:

(1) Dalam hal perbuatan sebagaimana dimaksud dalam Pasal 103, Pasal 104, Pasal 105, Pasal 106, Pasal 107, Pasal 108, dan Pasal 109 dilakukan oleh korporasi, selain pengurusnya dipidana berdasarkan Pasal 103, Pasal 104, Pasal 105, Pasal 106, Pasal 107, Pasal 108, dan Pasal 109, korporasinya dipidana dengan pidana denda maksimum ditambah 1/3 (sepertiga) dari pidana denda dari masing-masing tersebut.

Menurut penulis, ketentuan singkat di atas justru merupakan ketentuan yang lebih jelas mengenai tindak pidana korporasi. Pertama, jelaslah bahwa UU No. 39 Tahun 2014 menganut individual vicarious liability, dengan adanya pemidanaan kepada pengurus atas tindak pidana yang dilakukan untuk korporasi. Tindak 
pidana ini dapat saja dilakukan oleh pengurus sendiri, oleh pegawai bawahan, atau bahkan oleh korporasi itu sendiri.

Kedua, UU No. 39 Tahun 2014 membuka pula kemungkinan dijatuhkannya sanksi denda kepada korporasi. Karena UU tidak membatasi, maka pertanggungjawaban korporasi ini dapat didasarkan pada teori corporate vicarious liability, teori agregasi, teori identifikasi, atau bahkan teori budaya korporasi.

\section{e. Pertanggungjawaban Korporasi menurut RKUHP}

Pertanggungjawaban korporasi ternyata dirumuskan pula di dalam beberapa pasal RKUHP. Menurut Pasal 49: "Tindak pidana dilakukan oleh korporasi jika dilakukan oleh orang-orang yang mempunyai kedudukan fungsional dalam struktur organisasi korporasi yang bertindak untuk dan atas nama korporasi atau demi kepentingan korporasi, berdasarkan hubungan kerja atau berdasarkan hubungan lain, dalam lingkup usaha korporasi tersebut..."-[garis bawah dari penulis]. Selanjutnya di dalam penjelasan Penjelasan Pasal 49 dinyatakan pula bahwa "Kedudukan fungsional diartikan bahwa orang tersebut mempunyai kewenangan mewakili, kewenangan mengambil keputusan, dan kewenangan untuk menerapkan pengawasan terhadap korporasi tersebut...." Selanjutnya, dikatakan pula di dalam Pasal 50 bahwa: "Jika tindak pidana dilakukan oleh korporasi, pertanggungjawaban pidana dikenakan terhadap korporasi dan/atau pengurusnya atau personil pengendali korporasi".

Dari rumusan ini disimpulkan dua hal. Pertama, bahwa korporasi dianggap melakukan perbuatan pidana jika perbuatan itu dilakukan oleh pengurus/pemimpin korporasi (yang disubut "orangorang yang mempunyai kedudukan fungsional"). Kita bisa melihat bahwa sepertinya perancang RKUHP menganut teori identifikasi. Dengan demikian, menurut Pasal 49 dan 50, tidak ada perbuatan/pertanggungjawaban korporasi jika perbuatan pidana dilakukan oleh bawahan!

Memang RKUHP dalam Pasal 51 juga menyatakan bahwa "[k]orporasi dapat dipertanggungjawabkan secara pidana terhadap suatu perbuatan yang dilakukan untuk dan/atau atas nama korporasi, jika perbuatan tersebut termasuk dalam lingkup usahanya sebagaimana ditentukan dalam anggaran dasar atau ketentuan lain yang berlaku bagi korporasi yang bersangkutan." Rumusan ini cukup luas, sehingga sepintas dapat disimpulkan bahwa korporasi dapat diminta pertanggungjawaban pidana apabila pelaku pidana adalah bawahan atau apabila tindak pidana oleh bawahan ini terjadi karena adanya budaya atau kebijakan korporasi sendiri. Sayangnya, penjelasan Pasal 51 justru akan menegasikan kesimpulan ini, karena penjelasan ini menegaskan bahwa: 
Mengenai kedudukan sebagai pembuat tindak pidana dan sifat pertanggungjawaban pidana dari korporasi terdapat kemungkinan sebagai berikut:

a. pengurus korporasi sebagai pembuat tindak pidana dan oleh karena itu penguruslah yang bertanggung jawab;

b. korporasi sebagai pembuat tindak pidana dan pengurus yang bertanggung jawab; atau

c. korporasi sebagai pembuat tindak pidana dan juga sebagai yang bertanggung jawab. "-_garis bawah dari penulis].

Dari penjelasan di atas terlihat bahwa korporasi bertanggung jawab karena perbuatan pidana oleh pengurus, atau karena perbuatan pidana oleh korporasi sendiri. Karena pengurus tidak lain adalah orang dengan kedudukan fungsional di dalam korporasi, dan perbuatan oleh korporasi adalah perbuatan adalah orang dengan kedudukan fungsional tersebut, maka rumusan Pasal 51 dan penjelasannya ternyata tidak mengubah batasan pertanggungjawaban korporasi yand ada dalam Pasal 49. Akibatnya kesimpulan yang dihasilkan tetaplah sama, yaitu bahwa perbuatan dan pertanggungjawaban korporasi hanya ada jika pelaku perbuatan pidananya adalah pengurus!

Kesimpulan di atas patut disayangkan karena sebenarnya korporasi dapat bertanggungjawab tidak hanya atas perbuatan pemimpin/pengurus (teori identifikasi), tetapi juga atas perbuatan bawahan (teori corporate vicarious liability), atau bahkan karena perbuatan korporasi itu sendiri (model organisasi) atau agregasi perbuatan bawahan. Dalam model organisasi dan agregasi, korporasi bahkan bisa bertanggungjawab tanpa perlu adanya perbuatan pidana yang dilakukan oleh subjek hukum orang. Rumusan RKUHP perlu diubah karena rumusan tersebut sangat membatasi keberlakuan pertanggungjawaban korporasi, sehingga akan sangat sulit, jika tidak mungkin, untuk menerapkan pertanggungjawaban korporasi. Hal ini karena di dalam kenyataan sehari-hari hampir bisa dipastikan kita akan sangat sulit menemukan pengurus/pemimpin secara langsung memimpin dan melakukan tindak pidana.

Kedua, apabila Pasal 51 dan penjelasannya hendak diperluas penafsirannya sehingga juga meliputi pertanggungjawaban atas perbuatan pidana yang dilakukan oleh bawahan, maka RKUHP berarti membolehkan dijatuhkannya individual vicarious liability. Dalam hal ini, pemimpin/pengurus bertanggung jawab atas perbuatan bawahannya. Tentu saja karena tidak jelas batasannya, dan tidak jelas pula tindak pidana apa saja yang bisa dikenakan individual vicarious liability ini, maka perumusan Pasal 51 ini bisa menimbulkan 
kesimpangsiuran dalam penerapannya. Jika ini terjadi, maka RKUHP akan gagal membenahi dan mengoreksi berbagai kerancuan penerapan pertanggungjawaban korporasi yang selama ini terjadi. Kerancuan ini akan terlihat dari pembahasan pada sub Bagian berikut.

\section{Pertanggungjawaban Korporasi dalam Praktek: Beberapa Putusan Kasus Lingkungan Hidup terkait Pertanggungjawaban Korporasi}

Kasus yang perlu mendapat perhatian sebagai contoh dari penerapan pertanggungjawaban korporasi adalah kasus Republik Indonesia v. PT. Newmont Minahasa Raya dan Richard Bruce Ness (2005). Dalam kasus ini, JPU membagi pertanggungjawaban ke dalam pertanggungjawaban oleh badan hukum (PT. NMR) dan pertanggungjawaban pribadi pemimpin/pengurus korporasi (Richard Bruce Ness). Dalam kasus ini, secara cukup konsisten JPU menentukan bahwa Terdakwa I adalah badan hukum, yaitu PT. Newmont Minahasa Raya, dan Terdakwa II adalah orang, yaitu Richard Bruce Ness. ${ }^{83}$ Dalam kasus ini, JPU juga telah sangat baik dalam menjelaskan mengapa Richard Bruce Ness, seorang direktur, menjadi terdakwa. Dalam dakwaannya, secara konsisten JPU menjelaskan bahwa Terdakwa II berkontribusi dalam tindak pidana yang disangkakan. Terkait hal ini, JPU misalnya menyatakan bahwa Terdakwa II "memiliki tugas dan tanggung jawab untuk mengawasi, mengendalikan, dan memerintah staf di bawahnya supaya dapat melaksanakan tugas sesuai dengan ketentuan yang berlaku..." ${ }^{84}$ Pada sisi lain, JPU juga menyatakan bahwa Terdakwa II "ternyata tidak melakukan upaya untuk mencegah", atau "tetapi tetap saja membiarkan/tidak memerintahkan untuk dihentikannya" tindak pidana yang didakwakan. ${ }^{85}$ Dalam konstruksi ini, JPU mendakwa Richard Bruce Ness karena adanya kegagalan sebagai pemimpin/pengurus korporasi untuk menjalankan kewenangan pemimpin/pengurus guna mencegah terjadinya tindak pidana, dan bukan hanya karena kedudukan Richard Bruce Ness sebagai pemimpin/pengurus. Putusan PN yang membebaskan para Terdakwa tidak menunjukkan adanya kekeliruan JPU dalam merumuskan pertanggungjawaban korporasi dan pemimpin/ pengurus, melainkan karena persoalan pembuktian kausalitas dan juga penafsiran asas subsidiaritas.

Sementara itu, pada tahun 2010, MA mengeluarkan sebuah putusan yang sangat penting terkait bagaimana pertanggungjawaban korporasi

\footnotetext{
${ }^{83}$ Lihat: Putusan PN Manado No. 284/Pid.B/2005/PN.Mdo, Republik Indonesia v. PT. Newmont Minahasa Raya dan Richard Bruce Ness (2005), hal. 1.

${ }^{84}$ Putusan PN Manado No. 284/Pid.B/2005/PN.Mdo, Republik Indonesia v. PT. Newmont Minahasa Raya dan Richard Bruce Ness (2005), hal. 57.

85 Putusan PN Manado No. 284/Pid.B/2005/PN.Mdo, Republik Indonesia v. PT. Newmont Minahasa Raya dan Richard Bruce Ness (2005), hal. 64.
} 
diterapkan untuk kasus pencemaran lingkungan. Putusan ini adalah Putusan MA dalam kasus Republik Indonesia v. Kim Young Woo (2010). Kim Young Woo adalah direktur dari PT. Dongwoo Environmental Indonesia, sebuah perusahaan yang bergerak di bidang pengolahan limbah B3 dan telah memperoleh izin pengolahan limbah B3 berdasarkan SK Kepala Bapedal No. KEP-154/BAPEDAL/12/2001 tangga 107 Desember 2001, dan telah diperpanjang berdasarkan SK Menteri LH No. No.79 Tahun $2005 .{ }^{86}$ Dalam kasus ini, terdakwa yaitu Kim Young Woo didakwa berdasarkan Pasal 41 (1) UU No. 23 Tahun 1997 (untuk dakwaan primair), Pasal 43 (1) UU No. 23 Tahun 1997 Jo Pasal 45 UU No. 23 Tahun 1997 (untuk dakwaan subsidair), Pasal 42 (1) UU No. 23 Tahun 1997 (untuk dakwaan lebih subsidair), dan Pasal 44 (1) UU No. 23 Tahun 1997 (untuk dakwaan lebih subsidair lagi). ${ }^{87}$ Mahkamah Agung menyatakan bahwa "perbuatan Terdakwa dilakukan dalam kedudukan sebagai Presiden Direktur PT. Dongwoo Environmental Indonesia yang bergerak di bidang Pengelolaan Limbah B3....."88 Atas dasar itu, MA menyatakan bahwa "Terdakwa PT. Dongwoo Environmental Indonesia dalam hal ini diwakili oleh Kim Young Woo telah terbukti secara sah dan meyakinkan bersalah melakukan tindak pidana"-[italics dari penulis], dan karenanya "menjatuhkan pidana denda sebesar Rp. 650.000.000,- (enam ratus lima puluh juta rupiah ) dan apabila denda tersebut tidak dibayar maka diganti dengan pidana kurungan selama 6 (enum) bulan". 89

Putusan MA dalam Republik Indonesia v. Kim Young Woo (2010) menggambarkan adanya persoalan dalam penafsiran pertanggungjawaban korporasi di Indonesia. Dalam kasus ini secara jelas disebutkan pada halaman pertama bahwa yang menjadi terdakwa adalah Kim Young Woo. Akan tetapi, di dalam amar putusan disebutkan bahwa terdakwa adalah PT. Dongwoo Environmental Indonesia. Menurut penulis, antara Kim Young Woo sebagai subjek hukum orang, dan PT. Dongwoo Environmental Indonesia sebagai badan hukum, merupakan dua subjek hukum yang berbeda. Karena itu, kedua subjek hukum ini tidak bisa begitu saja bertukar kedudukannya. Artinya, apabila pada halaman pertama disebutkan bahwa terdakwa adalah Kim Young Woo, maka dalam amar pun terdakwa seharusnya Kim Young Woo, dan bukan PT. Dongwoo Environmental Indonesia.

\footnotetext{
(2010), hal. 2 .

${ }^{87}$ Mahkamah Agung, Putusan No. K/Pid .Sus /2010, Republik Indonesia v. Kim Young Woo (2010), hal. 86.

${ }^{88}$ Mahkamah Agung, Putusan No. K/Pid .Sus /2010, Republik Indonesia v. Kim Young Woo (2010), hal. 94.

${ }^{89}$ Mahkamah Agung, Putusan No. K/Pid .Sus /2010, Republik Indonesia v. Kim Young Woo (2010), hal. 95.
}

${ }^{86}$ Mahkamah Agung, Putusan No. K/Pid .Sus /2010, Republik Indonesia v. Kim Young Woo 
Kasus lainnya yang perlu diperhatikan adalah Putusan MA dalam kasus RI v. Ibrahim Lisaholit (2012). Dalam kasus ini, terdakwa adalah Ibrahim Lisaholit, yaitu manajer kebun (estate manager) dari sebuah korporasi, yaitu PT. Kalimantan Hamparan Sawit (PT. KHS). Dalam pertimbangannya, MA menyatakan bahwa "PT. KALIMANTAN HAMPARAN SAWIT (PT. KHS) telah lalai menyediakan alat-alat pemadam kebakaran/sangat minim..."-[garis bawah dari penulis].$^{90} \mathrm{Di}$ sisi lain, MA menyatakan pula bahwa "Terdakwa selaku Manager Estate PT. KALIMANTAN HAMPARAN SAWIT (PT. KHS), bertanggung jawab secara fungsional untuk PT. KALIMANTAN HAMPARAN SAWIT (PT. KHS) (functionele daderschap dalam korporasi) sehingga korporasi tersebut (PT. KHS) harus bertanggung jawab terhadap terjadinya kerusakan lingkungan tersebut, sekalipun Jaksa/Penuntut Umum tidak mendakwakan korporasi yang bersangkutan"-_ [garis bawah dari penulis]. ${ }^{91}$ Kelalaian inilah yang dianggap sebagai tindak pidana, sehingga MA menyatakan bahwa terdakwa terbukti "[k]arena kealpaannya mengakibatkan pencemaran dan/atau perusakan lingkungan hidup". 92

Putusan MA dalam RI v. Ibrahim Lisaholit memperlihatkan bahwa MA sepertinya tidak membedakan antara subjek hukum korporasi dan dengan terdakwa (orang). Sepertinya kedua subjek hukum ini dianggap sama dan karenanya perbuatan satu subjek hukum mengindikasikan pertanggungjawaban subjek hukum lainnya. Kesan seperti ini terlihat pada satu sisi dari kesimpulan MA yang menyatakan bahwa terdapat kelalaian dari PT. KHS padahal yang menjadi terdakwa adalah subjek hukum orang; dan pada sisi lain dari kesimpulan yang menyatakan bahwa karena subjek hukum orang (terdakwa) bertanggungjawab maka korporasi harus bertanggungjawab pula.

Terakhir, Putusan PN Pelalawan dalam Kasus Republik Indonesia v. Adei Plantation and Industry (2013), layak pula untuk diperhatikan. Dalam kasus ini, yang menjadi terdakwa adalah korporasi, yaitu PT. Adei Plantation. Selama persidangan, yang duduk sebagai wakil terdakwa adalah Tan Kei Yoong (subjek hukum orang), yang merupakan direktur dari terdakwa korporasi. Dalam amar putusannya, pengadilan menyatakan bahwa "terdakwa PT ADEI PLANTATION AND INDUSTRY telah terbukti secara sah dan meyakinkan bersalah melakukan tindak pidana "karena kelalaiannya mengakibatkan dilampauinya kriteria baku kerusakan lingkungan hidup" dan karenanya "menjatuhkan pidana kepada terdakwa oleh karena itu dengan pidana

\footnotetext{
90 Mahkamah Agung, Putusan No 1363 K/PID.SUS/2012, Republik Indonesia v. Ibrahim Lisaholit (2012), hal. 62.

91 Mahkamah Agung, Putusan No 1363 K/PID.SUS/2012, Republik Indonesia v. Ibrahim Lisaholit (2012), hal. 63.

92 Mahkamah Agung, Putusan No 1363 K/PID.SUS/2012, Republik Indonesia v. Ibrahim Lisaholit (2012), hal. 64.
} 
denda sebesar Rp. 1.5000.000.000,-... dengan ketentuan apabila denda tersebut tidak dibayar diganti dengan pidana kurungan yang diwakili oleh Sdr. Tan Kei Yoong selama 5 (lima) bulan"-[garis bawah dari penulis]. ${ }^{93}$ Dengan demikian, jika terdakwa tidak mampu membayar denda, maka Tan Kei Yoong, yang sebenarnya tidak pernah dijadikan terdakwa, akan dikenakan pidana kurungan. Jika ini terjadi, maka Tan Kei Yoong dapat dipidana tanpa pernah diadili!

\section{Kritik atas Pertanggungjawaban Korporasi di Indonesia}

Pembahasan pada bagian sebelumnya memperlihatkan adanya kerancuan dan kekeliruan mendasar dalam pemahaman pembuat undang-undang atau pun penegak hukum terkait pertanggungjawaban korporasi. Hal ini dapat dilihat dari beberapa hal yang ditemukan dalam tulisan ini: Pertama, terdapat beberapa undang-undang yang perumusannya dapat menimbulkan penafsiran bahwa korporasi dapat dijatuhi pidana penjara. Hal ini merupakan kekeliruan karena secara teori dan logika, tidak mungkin korporasi dikenakan sanksi pidana berupa penjara atau kurungan.

Kedua, terdapat rumusan yang dapat ditafsirkan bahwa apabila korporasi yang melakukan tindak pidana atau dijadikan terdakwa, maka sanksi dijatuhkan kepada pengurus/pemimpin korporasi. Penafsiran seperti ini tidaklah sepenuhnya tepat karena justru akan menimbulkan bahaya, yaitu berubahnya subjek hukum secara otomatis. Cara penafsiran ini tidak hanya keliru karena telah mencampuradukkan dan menganggap sama dua subjek hukum yang sesungguhnya berbeda, yaitu korporasi dan orang (pemimpin/ pengurus korporasi), tetapi juga memungkinkan dijatuhkannya pidana kepada orang orang (pemimpin/ pengurus korporasi) tanpa sebelumnya orang tersebut diadili (dijadikan terdakwa).

Penulis melihat bahwa persoalan dalam memahami pertanggungjawaban korporasi di atas terjadi karena setidaknya karena tiga hal:

1) Terdapat pemahaman yang menyamakan dan mencampuradukkan antara pertangungjawaban korporasi dengan pertanggungjawaban pemimpin/pengurus korporasi;

2) Tidak jelasnya kriteria untuk menentukan kapan dan atas perbuatan siapa korporasi bertanggungjawab.

3) Tidak adanya kriteria untuk menjelaskan kapan dan atas perbuatan siapa pemimpin/pengurus korporasi bertangungjawab.

Lebih jauh lagi penulis melihat bahwa kerancuan lebih terlihat lagi di dalam kaitannya dengan pertanggungjawaban pemimpin/pengurus korporasi. Hal ini, menurut penulis, terjadi karena dianutnya individual vicarious liability oleh perumus UU atau penegak hukum. Penulis sependapat dengan beberapa ahli hukum bahwa individual vicarious liability tidak begitu sejalan dengan

${ }^{93}$ PN Pelalawan Putusan No. 228/Pid.Sus/2013/PN.Plw, Republik Indonesia v. Adei Plantation (2013), hal. 226. 
pandangan umum mengenai pertanggungjawaban pidana. Pada dasarnya, seseorang pemimpin/pengurus tidak bisa dimintai pertanggungjawaban atas perbuatan orang lain hanya karena pemimpin/pengurus ini memegang posisi sebagai pemimpin/pengurus.

Menurut penulis, secara konseptual individual vicarious liability menimbulkan kerancuan dan campur aduk antara subjek hukum orang dengan subjek hukum badan hukum. Pertanggungjawaban seperti ini dapat menimbulkan kesan bahwa perbuatan/pertanggungjawaban badan hukum secara otomatis mengindikasikan pula adanya pertanggungjawaban subjek hukum orang. Akibatnya, dapat saja terjadi seorang pemimpin/pengurus bertangungjawab dan menjalankan sanksi pidana, padahal ia tidak pernah menjadi terdakwa karena selama persidangan yang menjadi terdakwa adalah korporasi. Sebaliknya, bisa pula terjadi korporasi menjadi pihak yang dikenakan sanksi pidana, padahal selama persidangan yang menjadi terdakwa adalah pemimpin/pengurus korporasi tersebut. Menurut penulis, adalah keliru apabila kita memandang bahwa apabila korporasi dijadikan terdakwa maka pidana dapat dijatuhkan kepada dan dijalankan oleh pemimpin/pengurus. Jika kita menginginkan agar pemimpin/pengurus ini dipidana, maka mereka haruslah dijadikan terdakwa pula!

Individual vicarious liability juga bermasalah karena bisa saja pengurus/pemimpin korporasi bertanggung jawab atas perbuatan pidana bawahan, meskipun pengurus/pemimpin ini telah melakukan upaya pencegahan dan kehati-hatian, meskipun pengurus/pemimpin tidak terlibat sama sekali dalam tindak pidana yang dilakukan, atau meskipun misalnya bawahan telah menutup-nutupi tindak pidana yang dilakukannya agar pengurus/pemimpin tidak mengetahui perbutan pidananya. Lebih jauh lagi, jika tujuan menjatuhkan pidana bagi pemimpin/pengurus adalah untuk memberikan insentif kepada mereka untuk melakukan segala upaya dalam mencegah tindak pidana, maka individual vicarious liability sebenarnya telah gagal untuk mencapai tujuan tersebut, karena ternyata pengurus/pemimpin tetap bertanggungjawab tanpa melihat apakah ia telah bertindak cermat untuk mencegah terjadinya tindak pidana atau tidak. ${ }^{94}$

${ }^{94}$ Kritik serupa juga ditujukan oleh Greenberg dan Brotman terhadap penerapan RCO di AS. Lihat: Joshua D. Greenberg and Ellen C. Brotman, "Strict Vicarious Criminal Liability for Corporations and Corporate Executives: Stretching the Boundaries of Criminalization", American Criminal Law Review, Vol. 51, 2014, hal. 94. Menurut penulis, Greenberg dan Brotman tidak sepenuhnya tepat dalam menyamakan anatara individual vicarious liability dengan RCO, justru karena RCO masih mensyaratkan adanya kegagalan dalam pengawasan dan pencegahan, serta tidak melekatkan pertanggungjawaban kepada seseorang hanya karena kedudukan dia sebagai seorang atasan. Kritik Greenberg dan Brotman, menurut penulis, lebih tepat diarahkan kepada individual vicarious liability. 


\section{Penutup}

\section{Simpulan}

Tulisan ini telah memaparkan beberapa hal terkait tindak pidana korporasi, pertanggungjawaban korporasi dan pertanggungajwaban pemimpin/pengurus korporasi, sebagaimana terangkum dalam Lampiran dari tulisan ini, masing-masing pertanggungjawaban tersebut memerlukan kriterianya sendiri-sendiri. Karena undang-undang di Indonesia sebagian besar tidak menjelaskan (atau menjelaskan dengan tidak jelas) pertanggungjawaban korporasi apa yang dianut, maka penegak hukum memiliki kebebasan dan tanggung jawab yang besar untuk merumuskan dan menafsirkan undang-undang tersebut. Satu hal yang sangat penting untuk diperhatikan adalah bahwa karena setiap teori yang akan digunakan membutuhkan kriterianya masing-masing, maka pilihan teori yang akan digunakan sedikit banyak terkait pula dengan sejauh mana bukti yang tersedia dapat mendukung kriteria ini.

Dari rumusan beberapa ketentuan dan penafsiran beberapa kasus, terlihat bahwa pemimpin atau pengurus korporasi seolah-olah secara otomatis bertanggungjawab atas tindak pidana di dalam lingkup kerja korporasi yang dilakukan oleh siapa pun, hanya karena kedudukannya sebagai pemimpin atau pengurus korporasi. Inilah yang disebut sebagai individual vicarious liability. Penulis menyetujui pendapat Allen atau Jefferson yang menyatakan bahwa meskipun dalam konteks perdata individual vicarious liability sudah jamak ditemukan, akan tetapi dalam konteks pidana individual vicarious liability sebaiknya dihindari. Karena itulah, apabila hendak memasukkan pula pemimpin/pengurus korporasi sebagai terdakwa, maka diperlukan bukti lain selain fakta bahwa mereka adalah pemimpin/pengurus korporasi. Bukti itu dapat berupa partisipasi atau kegagalan dalam mengawasi atau mencegah tindak pidana, sebagaimana dirumuskan dalam beberapa ketentuan pidana untuk pengurus korporasi di AS, Inggris, dan beberapa negara bagian di Australia.

\section{Saran}

Khusus mengenai RKUHP, menurut penulis akan lebih jelas apabila Pasal 49 dan Penjelasannya, serta Penjelasan Pasal 51 (dari RKUHP versi Juni 2015) dihilangkan. Cukup apabila rumusan yang dimuat adalah rumusan pertanggungjawaban korporasi menurut Pasal 51. Tentu saja jika ingin lebih baik lagi, maka Pasal 50 RKUHP sebaiknya juga diubah sehingga secara jelas menyatakan bahwa apabila korporasi dianggap bertanggungjawab karena perbuatan pidana yang dilakukan oleh atau untuk dan/atau atas nama korporasi, maka pemimpin/pengurus dianggap telah pula gagal melakukan pengawasan dan pencegahan sehingga ia harus pula bertanggungjawab. Pemimipin/pengurus ini dapat lepas dari pertanggungjawaban apabila ia mampu membuktikan tidak memiliki 
kewenangan untuk menghentikan tindak pidana, atau telah melakukan upaya yang layak untuk mengawasi dan mencegah dilakukannya tindak pidana. 


\section{Daftar Pustaka}

\section{Buku/Artikel Jurnal}

Aagaard, Todd S. "A Fresh Look At The Responsible Relation Doctrine", Journal of Criminal Law \& Criminology, Vol. 96, 2006.

Allen, Michael J. Textbook on Criminal Law, 7th ed. Oxford: Oxford University Press, 2003.

Anderson, Helen. "Directors' Liability for Corporate Faults and Defaults-An International Comparison”, Pacific Rim Law \& Policy Journal, Vol. 18, January, 2009.

Bernau, Patrick. Decision and Punishment: Or-Hold Bankers Responsible!: Corporate Criminal Liability fromcan Economic Perspective, dalam: Dominik Brodowski, et al. (eds.), Regulating Corporate Criminal Liability. Dordrecht: Springer, 2014.

Bragg, Jennifer; John Bentivoglio; dan Andrew Collins. "Onus of Responsibility: The Changing Responsible Corporate Officer Doctrine”, Food and Drug Law Journal, Vol. 65, 2010.

Card, Richard. Criminal Law. $21^{\text {st }}$ ed. Oxford: Oxford University Press, 2012.

Clinard, Marshall B.; dan Peter C. Yeager. Corporate Crime. New York: The Free Press, 1980.

Elliott, Catherine; dan Frances Quinn. Criminal Law. $3^{\text {rd }}$ ed. Essex: Pearson Education, Ltd., 2000.

Fisse, Brent; dan John Braithwaite (1988). "The Allocation of Responsibility for Corporate Crime: Individualism, Collectivism and Accountability”, Sydney Law Review, Vol. 11, 1988.

Fisse, Brent; dan John Braithwaite (1993). Corporations, Crime and Accountability. Cambridge: Cambridge University Press, 1993.

Foster, Neil. “Individual Liability of Company Officers”. Dalam: James Gobert dan Ana-Maria Pascal (eds.), European Developments in Corporate Criminal Liability. London: Routledge, 2011.

Gobert, James The Evolving Legal Test of Corporate Criminal Liability, Dalam: John Minkes dan Leonard Minkes (eds.), Corporate and Whitecollar Crime. London: Sage Publications Ltd., 2008.

Gobert, James. Squaring the Circle: The Relationship between Individual and Organizational Fault, dalam: James Gobert dan Ana-Maria Pascal (eds.). European Developments in Corporate Criminal Liability. London: Routledge, 2011.

Greenberg, Joshua D. dan Ellen C. Brotman. "Strict Vicarious Criminal Liability for Corporations and Corporate Executives: Stretching the 
Boundaries of Criminalization", American Criminal Law Review, Vol. $51,2014$.

Harding, Christopher. Criminal Enterprise: Individuals, Organisations and Criminal Responsibility. Portland: Willan Publishing, 2007.

Henning, Peter J. "A New Crime For Corporate Misconduct?”, Mississippi Law Journal, Vol. 84, 2014.

Keulen, Berend F.; and Erik Gritter. Corporate Criminal Liability in the Netherlands, dalam: Mark Pieth dan Radha Ivory (eds.). Corporate Criminal Liability: Emergence, Convergence, And Risk. Dordrecht: Springer, 2011.

Kushner, Amiad. "Applying The Responsible Corporate Officer Doctrine Outside the Public Welfare Context”, Journal of Criminal Law \& Criminology, Vol. 93, 2003.

Mullikin, Nancy. "Holding the "Responsible Corporate Officer" Responsible: Addressing the Need for Expansion of Criminal Liability for Corporate Environmental Violators", Golden Gate University Environmental Law Journal, Vol. 3, 2010.

The Law Commission, "Criminal Law: Involuntary Manslaughter", Consultation Paper No 135, tersedia pada: <http://www.lawcom.gov.uk/ wp-content/uploads/2015/06/No.135-Criminal-Law-Involuntary-

Manslaughter-A-Consultation-Paper.pdf>, diakses pada bulan Mei 2016.

The Law Commission of England and Wales. "Criminal Liability in Regulatory Contexts: A Consultation Paper”, Consultation Paper No 195, 2010. Tersedia pada <http://www.lawcom.gov.uk/wp-content/ uploads/2015/06/cp195_Criminal_Liability_consultation.pdf>, diakses pada Februari 2016.

de Maglie, Cristina. "Models of Corporate Criminal Liability in Comparative Law”, Washington University Global Studies Law Review, Vol. 4(3), 2005.

Pieth, Mark; dan Radha Ivory. Emergence and Convergence: Corporate Criminal Liability Principles in Overview, dalam: Mark Pieth dan Radha Ivory (eds.), Corporate Criminal Liability: Emergence, Convergence, and Risk. Dordrecht: Springer, 2011.

Pinto, Amanda; dan Martin Evans. Corporate Criminal Liability. London: Sweet and Maxwell, 2003.

Punch, Maurice. The Organizational Component in Corporate Crime, dalam: James Gobert dan Ana-Maria Pascal (eds.). European Developments in Corporate Criminal Liability. London: Routledge, 2011.

Rahmadi, Takdir. Hukum Lingkungan di Indonesia, Ed. II. Jakarta: Raja Grafindo Persada, 2011. 
Sarre, Rick. Penalising Corporate 'Culture': The Key to Safer Corporate Activity?, dalam: James Gobert dan Ana-Maria Pascal (eds.). European Developments in Corporate Criminal Liability. London: Routledge, 2011.

Sjahdeini, Sutan Remy. Pertanggungjawaban Pidana Korporasi, Cet. II. Jakarta: Grafiti Press, 2007.

Stern, Yedidia Z. "Corporate Criminal Personal Liability: Who is the Corporation?”, Journal of Corporation Law, Vol. 13(1), 1987.

Stessens, Guy. "Corporate Criminal Liability: A Comparative Perspective", The International and Comparative Law Quarterly, Vol. 43(3), 1994.

Webb, Dan K.; Steven F. Molo; dan James F. Hurst. "Understanding and Avoiding Corporate and Executive Criminal Liability", The Business Lawyer, Vol. 49(2), February 1994.

Yarosky, Harvey. "The Criminal Liability of Corporations", McGill Law Journal, Vol. 10(2), 1964.

\section{Putusan Pengadilan}

Mahkamah Agung, Putusan No. K/Pid .Sus /2010, Republik Indonesia v. Kim Young Woo (2010).

Mahkamah Agung, Putusan No 1363 K/PID.SUS/2012, Republik Indonesia v. Ibrahim Lisaholit (2012).

PN Manado, Putusan No. 284/Pid.B/2005/PN.Mdo, Republik Indonesia v. PT. Newmont Minahasa Raya dan Richard Bruce Ness (2005).

PN Pelalawan, Putusan No. 228/Pid.Sus/2013/PN.Plw, Republik Indonesia v. Adei Plantation and Industr (2013).

United States v. Twentieth Century Fox Film Corp., 882 F.2d 656 (2d Cir 1989).

United States v. Bank of New England, N.A., 821 F.2d 844 (1st Cir 1987). 